\title{
A Plea for Consumer Protection: The Potential HUMAN HEALTH HAZARDS OF THE SPRAY TANNING EPIDEMIC
}

\author{
JESSICA M. DUGDALE*
}

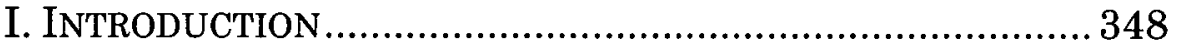

II. SPRAY TAN SOLUTIONS................................................. 354

A. Dihydroxyacetone (DHA) ....................................... 355

B. DHA Application Approved for External Use Only... 357

C. Adverse health Effects of Spray Tan Application ..... 358

D. DHA has no Regulatory Status.............................. 360

III. INITIAL GOVERNMENTAL RESPONSE TO INDOOR TANNING

REGULATION

A. Governmental Response to Indoor UV Tanning ....... 361

B. Governmental Response to Indoor Sunless Tanning 365 IV. CURRENT INDOOR TANNING REGULATIONS ...................... 366

A. Federal Indoor Tanning Regulations......................... 366

1. The FDA: Regulating Color Additives and Tanning

Devices Under the FFDCA 367

2. The FTC: Regulating Advertising Claims by the Indoor Tanning Industry ...................................... 372

3. Tanning Accountability and Notification Act of

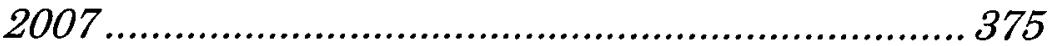

4. Tanning Tax........................................................ 376

B. State Tanning Regulations....................................... 377

1. State Indoor UV Tanning Regulations .................... 378

2. State Indoor Spray Tanning Regulations............... 382

3. Indiana Spray Tanning Regulations ...................... 383

V. FUTURE INDOOR SPRAY TANNING REGULATIONS................ 385

A. Rigorous Federal Regulation of the Indoor Spray

Tanning Industry .................................................... 385

B. Enhanced State and Local Health Authority

Regulation of Indoor Spray Tanning.... 387

C. Nationwide Minimum Age Requirements for Indoor

* J.D. Candidate, 2014, Indiana University Robert H. McKinney School of Law, Indianapolis, Indiana; B.A., December 2010, DePauw University, Greencastle, Indiana. 
Spray Tanning ........................................................ 388

VI. REGULATORY ALTERNATIVES .......................................... 390

A. Promoting Consumer Education................................ 390

B. Encouraging Self-Regulation, Operator Education, and Appropriate Advertising by Salons ................... 393

C. Endorsing Safer Alternatives to Achieving a Tanned Appearance ........................................................ 395

D. Changing Perceptions About Desirable Skin Colors. 396 VII. CONCLUSION................................................................... 397

\section{INTRODUCTION}

Human skin performs several critical functions including protection, sensation, temperature regulation, storage, excretion, absorption, and water resistance. ${ }^{1}$ Being the largest organ and most visible part of the human body, the skin deserves adequate protection from external sources of potential harm. Human skin, however, is frequently exposed to the sun, and many United States (U.S.) consumers have become engrossed with sustaining a bronzed appearance. ${ }^{2}$

In the U.S., communities have long been plagued by skin color politics. ${ }^{3}$ The historical roots of skin color stratification indicate differing reactions to light skin tones. ${ }^{4}$ Once an indicator of an elegant lifestyle, a fair

1 U.S. Dep't of Health and Human Servs., Radiation-Emitting Products: Basic Skin Anatomy, U.S. FOOD AND DRUG ADMIN., http://www.fda.gov/Radiation-EmittingProducts/

RadiationEmittingProductsandProcedures/Tanning/ucm $116428 . \mathrm{htm}$ (last updated May 4, 2009).

2 Daniel J. Sheehan \& Jack L. Lesher, Jr., The Effect of Sunless Tanning on Behavior in the Sun: A Pilot Study, 98 S. MED. J. 1192 (2005).

3 Margaret Hunter, SkIN DeEP: How RACE AND Complexion MATTER IN THE "COLOR-BLIND" ERA, 22-38 (Cedric Herring et al eds., 2004).

$4 \quad$ Id. at 22. 
complexion is typically no longer desirable in the U.S. 5 Evidence of a culture that presently encourages compulsive tanning, the current coveted appearance includes a bronzed skin tone. ${ }^{6}$ A 2009 study explains, "cultural attitudes shifted dramatically to favor skin tanning for cosmetic reasons during 1928 and . . . tanning has been a cultural norm in the [U.S] for approximately [four] generations."7 Indoor tanning salons provide individual beds comprised of tanning lamps that expose consumers to high intensities of ultraviolet (UV) rays in short doses to produce a tanned appearance. ${ }^{8}$ Similarly, indoor tanning salons offer UV-free tanning whereby spray tanning devices coat the skin with a sunless tanning solution to deliver a faux glow. ${ }^{9}$

5 Andrea Y. Loh, Note, Are Artificial Tans the New Cigarette? How Plaintiffs Can Use the Lessons of Tobacco Litigation in Bringing Claims Against the Indoor Tanning Industry, 107 MICH. L. REV. 365, 366 (2008) (citing HUNTER, supra note 3, at 23).

6 Id. (citing Julie Rawe, Why Teens Are Obsessed with Tanning, TIME, July 6, 2006, at 1 (discussing the "frightening spike in cancer rates among the young," increasing incidence of melanoma, and estimating that 2.3 million teens supported the $\$ 5$ billion-a-year tanning industry as of 2006)); see Mary T. Pawlak et al., Legislation Restricting Access to Indoor Tanning Throughout the World, $148 \mathrm{ARCH}$. DERMATOL. 1006 (2012) ("On average, [one] million people use tanning beds per day in the United States, and nearly [twenty-eight] million people use tanning beds annually.") (internal citations omitted).

7 Jo M. Martin et al., Changes in Skin Tanning Attitudes: Fashion Articles and Advertisements in the Early 20th Century, 99 AM. J. OF PUB. HEALTH 2140, 2145 (2009), available at http://ajph.aphapublications.org/doi/pdf/10.2105/AJPH.2008.144352

(examining changes in tanning attitudes portrayed in popular women's press in the 1920s and 1930s); see, e.g., Jane Brody, $A$ Healthy Glow That's Truly Healthy, NEW YORK TIMES (July 6, 2009), http://www.nytimes.com/2009/06/02/health/02brod.html?_r=0

(discussing attitudes about tans whereby a 2009 survey "found that the more westernized the respondents, the more positive their attitudes toward tanning and sunbathing.").

8 U.S. Dep't of Health and Human Servs., Radiation-Emitting Products: Tanning Products, U.S. FOOD AND DRUG ADMIN., http://www.fda.gov/Radiation-EmittingProducts/

RadiationEmittingProductsandProcedures/Tanning/ucm 116434.htm (last updated Apr. 17, 2013).

$9 \quad I d$. 
The dangers of UV exposure are of increasing concern to frequent sun-seekers, and a 2009 World Health Organization (WHO) study confirmed that fear by declaring tanning beds to be carcinogenic. ${ }^{10}$ Linking detrimental health effects to sun exposure, including premature skin aging and an increased risk of cancer, many consumers have turned to sunless tanning alternatives. ${ }^{11}$ Between 2003 and 2008, sales of sunless tanning products quadrupled. ${ }^{12}$ The National Toxicology Program suggests, "[s]unless tanning products represent about $10 \%$ of the $\$ 400$ million market for suntan preparations, and these products are the fastest growing segment." 13 Though advocated as a safer alternative to UV exposure, sunless tanning may not

10 Veronica Knapp, Note, FDA's Regulation of Tanning Beds: How Much Heat?, 66 FoOD \& DRUG L.J. 25 (2011) (internal citation omitted).

11 Bruce A. Brod, Tanning Industry Exposed: Evidence Demonstrates Link Between Indoor Tanning and Skin Cancer, AAD.ORG (Aug. 16, 2012), http://www.aad.org/stories-and-news/newsreleases/tanning-industry-exposed-evidence-demonstrates-link-betweenindoor-tanning-and-skin-cancer-dermatologists-committed-to-educatingpublic'on-risks (last visited July 6, 2013); Jennifer M. Fu et al., Sunless Tanning, 50 J. AM. ACAD. DERMATOL. 706 (2004); Sheehan \& Lesher, supra note 2, at 1194 ("In recent years the American public has become more aware of sunless tanning methods as an alternative to UVD tanning, and as the newer sunless tanning formulations provide a cosmetically improved color, their use has increased.") (internal citations omitted); see Lawrence G. Cetrulo, Spray Tan Litigation, in 4 TOXIC TORTS LITIGATION GUIDE $\S 38: 14$ (2012) ("Spray tans as an alternative to [UV] radiation from tanning beds have become increasingly trendy.") (internal citation omitted).

12 Anne Mahoney et al., Attitudes Toward Indoor Tanning Among Users of Sunless Tanning Products, 148 ARCH. DERMATOL. 124, 124-126 (2012) (citing Christopher Muther, You're Not Bronzed: That Tan is Fake!, THE BOSTON GLOBE (May 21, 2009), http://www.boston.com/ lifestyle/fashion/articles/2009/05/21/youre_not_bronzed_that_tan_is_fak e/ ("Sales of self-tanners in the United States have skyrocketed in the past five years. In 2003, sales totaled $\$ 53$ million. By 2008, sales surpassed $\$ 200$ million, according to market research group Mintel International Group, Ltd.")).

13 U.S. Dep't of Health and Human Servs., Summary of Data for Chemical Selection: Dihydroxyacetone 96-26-4, NAT'L TOXICOLOGY PROGRAM (Feb. 21, 1998), http://ntp.niehs.nih.gov/ntp/htdocs/ Chem_Background/ExSumPdf/Dihydroxyacetone_508.pdf [hereinafter DHA Summary]. 
be a preventive measure. ${ }^{14}$ While there are no proven adverse health effects associated with the regular use of sunless tanning products, the uninvestigated effect of prolonged human exposure suggests that conceivable harms remain largely unknown. ${ }^{15}$

Since the introduction of spray tanning booths into the U.S. market in 1999, the indoor tanning industry has embraced this novel technology endorsed as a means to obtain healthy skin and a flawless glow. ${ }^{16}$ Spray tanning booths function by misting an even coat of sunless tanning solution onto a consumer's exposed skin. ${ }^{17}$ While spray tans have been available for a number of years, the general public has acted under the assumption that the U.S. Food and Drug Administration (FDA) has approved the use of spray tanning devices. This notion is incorrect.

In 1977, prior to the development of spray tans, the FDA approved the use of dihydroxyacetone (DHA) for external

14 Christine L. Paul et al., Harm Minimization in Tan Seekers: An Exploration of Tanning Behaviour and the Potential for Substitution Use of Sunless Tanning Products, 16 J. OF HEALTH PSYCHOL. 929, 934 (2011) ("[S] unless tanning products are considered a tanning add-on or top-up rather than a substitute for exposure to UV light.").

15 Mark Greenblatt \& Gitika Ahuja, Are 'Spray-On' Tans Safe? Experts Raise Questions as Industry Puts Out Warnings, ABC NEwS (June 12, 2012), http://abcnews.go.com/Health/safety-popular-spraytans-question-protected/story?id=16542918 ("None of the reviewed studies tested on actual human subjects, but some found DHA altered genes of multiple types of cells and organisms when tested in different labs by different scientists after the chemical was approved for use in the consumer market.").

16 Fu et al., supra note 11, at 709 (citing Kerry Curry, Sunless Tan System Heats Up Sales for Cowtown Firm, Dallas Business Journal (Apr. 14, 2002 11:00 PM CDT), http://www.bizjournals.com/dallas/ stories/2002/04/15/story2.html).

$17 I d$. at 706 ("Never before has a cosmetically acceptable, fullbody, sunless tan been so accessible and so affordable for the masses."). While this Note focuses exclusively upon the human health hazards associated with routine spray tan exposure, the sunless tanning mist emitted from spray tan booths may implicate Clean Air Act violations as well. See Clean Air Act, 42 U.S.C. $§ 7401$, et seq. (2012) ("[A]ir pollution prevention (that is, the reduction or elimination, through any measures, of the amount of pollutants produced or created at that source) and air pollution control at its source is the primary responsibility of the States and local governments."). 
application only. ${ }^{18}$ DHA is the primary chemical ingredient used in spray tan solutions and is a commonly used color additive that reacts with amino acids in the skin's surface causing dead skin cells to darken. ${ }^{19}$ This chemical ingredient is not unique to sunless tanning booths in the U.S., as DHA has been used in cosmetic products worldwide. ${ }^{20}$

The Federal Food, Drug, and Cosmetic Act (FFDCA) empowers the FDA to oversee the safety of food, drugs, and cosmetics in the U.S. ${ }^{21}$ While DHA is a "color additive" exempt from the certification requirements of the FFDCA, FDA certification is required in order for DHA to be used in cosmetic products. ${ }^{22}$ A "color additive" is defined by the Code of Federal Regulations (CFR) to mean:

a dye, pigment, or other substance made by a process of synthesis or similar artifice, or extracted, isolated, or otherwise derived, with or without intermediate or final change of identity, from a vegetable, animal, mineral, or other source and that, when added or applied to a food, drug, or cosmetic or to the human body or any part thereof, is capable (alone or through reaction with another substance) of imparting a color thereto. ${ }^{23}$

1821 C.F.R. $\$ 73.2150$ (2013).

19 Due to the reactive relationship between DHA and human skin, "[m] ost sunless tanning products contain the active ingredient [DHA]." Sheehan \& Lesher, supra note 2, at 1194 (describing DHA as "a 3carbon sugar that combines covalently with basic groups of proteins in the stratum corneum in a browning reaction known as the Maillard reaction.").

20 European Comm'n, Scientific Committee on Consumer Safety: Opinion on Dihydroxyacetone, EC.EUROPA.EU (Dec. 14, 2010), http://ec.europa.eu/health/scientific_committees/consumer_safety/docs/sc cs_o_048.pdf .

21 Federal Food, Drug, and Cosmetic Act, Pub. L. No. 75-717, 52 Stat. 1040 (1938) (codified at 21 U.S.C. $\$ 301$ (2013)).

$22 \quad 21$ C.F.R. $\S 73.1150(\mathrm{e}) \mathrm{a}$.

$23 \quad$ Id. $\S 70.3(\mathrm{f})$. 
If a consumer inhales or ingests DHA during spray tan application, the consumer is not sufficiently protected from its unapproved use. ${ }^{24}$ While manufacturers and salon professionals have a duty to ensure that DHA-containing cosmetic products are marketed, labeled, and appropriately used under customary conditions, the national and local health authorities must oversee the proper administration of sunless tanning products, including spray tanning booths. ${ }^{25}$

Spray tanning has no proven adverse health effects apart from allergic reactions. ${ }^{26}$ Nevertheless, the FDA is clear that DHA should not be inhaled or ingested because no safety data to support the regular human use of DHA as an all-over spray has been submitted to the FDA for evaluation. ${ }^{27}$ While the FDA has approved DHA to be externally applied for skin darkening, it states that DHA "should not be inhaled, ingested, or exposed to areas covered by mucous membranes including the lips, nose, and areas in and around the eye" due to uninvestigated health risks. ${ }^{28}$ Because the tanning industry "has not provided safety data to [the] FDA in order for the agency to consider approving it for use on these exposure routes, including 'misting' from tanning booths," the use of DHA as an all-over spray has not yet been approved. ${ }^{29}$

A 2003 study found that a majority of businesses with spray tanning booths largely lacked "recommendations for protection of the entire area of the eye as defined by the FDA, the lips, and the mucous membranes." 30 Arguably,

24 U.S. Dep't of Health and Human Servs., Cosmetics: Sunless Tanners and Bronzers, U.S. FOOD AND DRUG ADMIN., http://www.fda.gov/Cosmetics/ProductandIngredientSafety/ProductInfor mation/ucm 134064.htm (last visited July 6, 2013) [hereinafter Sunless Tanners Guidance].

25 Id.

26 Nevertheless, increasing usage of spray tanning "may pose health risks . . . that could develop into future toxic tort litigation." Cetrulo, supra note 11 (internal citation omitted).

27 Sunless Tanners Guidance, supra note 24.

28 Id.

29 Id.

$30 \quad$ Fu et al., supra note 11 , at 712 (discussing that the majority of sunless tanning businesses suggested that consumers "close their eyes 
spray tanning salons are not adequately protecting consumers. Not only do consumers have the right to be protected from the potential risks of DHA exposure, but consumers also have the right to be sufficiently informed of the uninvestigated nature of the primary tanning ingredient employed by spray tanning booths.

This Note discusses the inadequate legal protection of consumers who utilize spray tanning booths, which have not been approved by the FDA due to a lack of safety data supporting regular human exposure. This Note explores both past and present federal and state regulation of the indoor tanning industry and examines the effectiveness of that regulation in protecting consumers. To advocate for a comprehensive approach toward increasing consumer protection through more stringent spray tanning regulations as well as non-regulatory measures, Section II discusses the general background, ingredients, approved uses, known adverse effects, and current regulation of sunless tanning solutions. Section III analyzes the evolution of the indoor tanning industry, comparing the regulation of indoor UV tanning to the lack of regulation of spray tanning. Likewise, Section IV elaborates on the differences between federal and state regulation of indoor UV and spray tanning. Section V of this Note offers predictions and recommendations for future spray tanning regulations, and Section VI examines non-regulatory alternatives that may provide greater consumer protection. Section VII will conclude the Note.

\section{SPRAY TAN SOLUTIONS}

This Note advocates for a comprehensive approach toward increasing consumer protection, which includes the implementation of more stringent spray tanning regulations in addition to non-regulatory alternative measures. Understanding the ingredients, current regulation, and unknown risks of spray tan solutions are important in advocating for greater consumer protection. This section

(100\% 17/17), hold their breath (77\% 13/17), and implement postsunless tanning sun precautions (82\% 14/17)."). 
explains the general background of the primary chemical ingredient in spray tan solutions: DHA. This section also covers definitions found within the CFR that pertain to DHA, offers details about other ingredients commonly found in spray tan solutions, and explains how the lack of current DHA regulation may adversely affect consumers.

\section{A. Dihydroxyacetone (DHA)}

DHA is known as the primary active ingredient in spray $\tan$ solutions that causes the human skin to darken. ${ }^{31}$ While proponents express that spray tanning is a safer alternative to sunbathing, accidental inhalation or ingestion of DHA during spray tan application may have a host of unknown, unproven health risks. ${ }^{32}$ Further, "knowledge about the potential toxicity and mutagenicity of DHA is very limited." 33 No long-term human studies have been undertaken to examine the health effects associated with the regular use of DHA-based tanning solutions. ${ }^{34}$

Evidence suggests that DHA presents "a risk of doing serious damage at a cellular level." 35 Thus, DHA could have mutagenic potential, and "[t]he genotoxic capacity of DHA raises a question about the long-term clinical consequences of treatment of the skin with this commonly used compound." 36 Because of the uninvestigated health effects of DHA, spray tan consumers could be routinely engaging in an activity unaware of the potential consequences.

In 2012, ABC News compiled ten recent studies that examined "chemicals used in tanning sprays and asked a

31 Anita B. Peterson et al., Dihydroxyacetone, the Active Browning Ingredient in Sunless Tanning Lotions Induces DNA Damage, CellCycle Block, and Apoptosis in Cultured HaCaT Keratinocytes, 560 MUTATION RESEARCH/GENETIC TOXICOLOGY AND ENVT'L MUTAGENESIS 173, 173-74 (2004), available at $\mathrm{http}: / / \mathrm{www}$. sciencedirect.com/science/ article/pii/S1383571804000555.

32 Sunless Tanners Guidance, supra note 24.

33 Peterson et al., supra note 31, at 174.

34 Beth Levine, Spray Tan Dangers, The Baseline of Health FOUNDATION (Jun. 26, 2012), http://www.jonbarron.org/article/spraytan-dangers.

35 Id.

36 Peterson et al., supra note 31, at 185. 
panel of medical specialists in fields such as dermatology, pulmonary medicine, and toxicology to provide an analysis . . . [and found that] problems stem from the active ingredient used in these tanning products, a chemical called [DHA]."37 Precautions such as nose plugs, eye protection, and lip balm may decrease the accidental inhalation or ingestion of DHA during spray tan application; however, salons may not offer or advocate for such precautions because of the undesirable "tan lines" that may result from use of precautionary methods.

Despite possible preventative measures, external application of DHA results in absorption by the skin. Thus, "[e]ven though the DHA-induced browning of the skin is limited to the outer layer of the [skin] it has been reported that DHA is detectable in the blood stream quickly after topical application."38 If DHA is absorbed through the skin, it may begin "[c]irculating in the blood stream, [and] may also be able to affect [deoxyribonucleic acid (DNA)] and proteins in other cells of the organism." 39 As there is evidence of harm associated with the absorption of DHA through the human skin, spray tanning facilities must be regulated.

As early as 1980 , a study demonstrated that tanning lotions containing DHA caused primary DNA damage. ${ }^{40} \mathrm{~A}$ similar mutation research study, conducted in 2004, revealed that DHA "induces DNA damage, cell-cycle block and apoptosis in cultured keratinocytes." 41 Alarmingly, "[t]he DHA concentrations (up to $100 \mathrm{mM}$ ) used in this investigation are below those found in commercially

37 Levine, supra note 34.

38 Peterson et al., supra note 31 , at 181-85 ("[T] $]$ he low molecular weight of DHA (152.1 Da) enables its penetration through the skin.") (internal citations omitted).

39 Id. at 185.

$40 \quad I d$. at 174.

41 Id. at $181-82$ (stating that these "results were obtained with a cultured keratinocyte cell line and there is no evidence that DHA induces the same biological effects in human epidermis.") ("The timeand dose-dependent decrease in viability and the inhibition of clonal growth suggest a direct toxic effect caused by DHA or by AGE-modified proteins leading to cell death."). 
available sunless tanning lotions $(\geq 330 \mathrm{mM})$." 42 These studies make it clear that further research is necessary to determine whether DHA may prove to be detrimental to human health.

DHA, however, is not the sole component of spray tanning solutions. Many sunless tanning products "typically contain $3 \%$ to $5 \% \mathrm{DHA}$, in combination with any number of additional ingredients, including sunscreens, bronzers, vitamins, botanical extracts, antioxidants, and alpha-hydroxy acids." 43 Spray tan solution ingredients often include: witch hazel, propellant, preservatives, stabilizer, and more. ${ }^{44}$ As DHA is the primary skin-staining component, it is the most desirable ingredient of sunless tanning products. Because nearly all sunless tanning products contain this active ingredient, more research is necessary to thoroughly investigate any potentially harmful consequences associated with DHA application, absorption, ingestion, and inhalation.

\section{B. DHA Application Approved for External Use Only}

Color additives are subject to FDA regulation. ${ }^{45}$ The FFDCA authorizes the FDA's regulation of color additives and lists DHA for use in imparting color to the human body (including sunless tanning products), but DHA is restricted to external application. ${ }^{46}$ The FFDCA defines the term "cosmetic" to mean "articles intended to be rubbed, poured, sprinkled, or sprayed on, introduced into, or otherwise applied to the human body or any part thereof for cleansing,

$42 \quad$ Id. at 185.

43 Fu et al., supra note 11 , at 709.

44 Linda Tarr Kent, Spray Tanning Ingredients, LIVESTRONG.COM (Jan. 2, 2010), http://www.livestrong.com/article/69273-spray-tanningingredients/.

45 "Cosmetic products and ingredients are not subject to FDA premarket approval authority, with the exception of color additives." U.S. Dep't of Health and Human Servs., FDA Authority Over Cosmetics, U.S. Food and Drug Admin., http://www.fda.gov/Cosmetics/

GuidanceComplianceRegulatoryInformation/ucm074162.htm

(last visited July 6, 2013) ("Cosmetic firms are responsible for substantiating the safety of their products and ingredients before marketing.").

$46 \quad 21$ C.F.R. $\S \S 70.3(\mathrm{v}), 70.5(\mathrm{a}), 73.2150$, (2013). 
beautifying, promoting attractiveness, or altering the appearance . . . "47 According to the CFR, "externally applied" cosmetics are those "applied only to external parts of the body and not to the lips or any body surface covered by mucous membrane." 48 Although spray tans are applied externally, it may be impossible to avoid DHA contact with the lips, nose, and areas of the eye during the misting application (an application for which DHA has not been approved). Thus, when imparted with color in a spray tan booth, consumers are not acting in compliance with FDA recommendations.

The FDA specifically prohibits DHA application near the eye. ${ }^{49}$ The CFR defines "area of the eye" as "the area enclosed within the circumference of the supra-orbital ridge and the infra-orbital ridge, including the eyebrow, the skin below the eyebrow, the eyelids and the eyelashes, and conjunctival sac of the eye, the eyeball, and the soft areolar tissue that lies within the perimeter of the infra-orbital ridge." 50 Seemingly, current spray tanning practices do not warn consumers of this risk. It is likely that DHA has come into contact with the area of the eye of many spray tan consumers, which has been specifically forbidden by the FDA. As the risks of such DHA exposure are currently unknown and under-investigated, sunless tanning practices should be regulated more thoroughly.

\section{Adverse Health Effects of Spray Tan Application}

Worldwide concerns about the safety of DHA in spray applications have flourished due to the possibility of consumer exposure by inhalation, an "exposure . . . quite different from DHA as an ingredient in self tanning creams, which occurs via the skin only." 51 Early studies were undertaken to investigate the chemical mechanism

\footnotetext{
4721 U.S.C. $\S 321(i)(1)$ (2013) (effective June 22, 2009).

$48 \quad 21$ C.F.R. $\$ 70.3(\mathrm{v})$.

49 See id. $\S 70.5(\mathrm{a})$.

50 See id. § 70.3(s).

51 European Comm'n, supra note 20.
} 
responsible for staining the skin.52 A 1960 University of Cincinnati College of Medicine study found that the combination of DHA and arginine, "one of the most important amino acid constituents of human skin . . . is probably responsible for the browning which is observed when human skin is treated with DHA." 53 Despite the absence of human-based studies, medical professionals suggest that DHA may be linked to cancer. ${ }^{54}$ Concerns about the negative effects of long-term DHA exposure are not unwarranted, as "[a]n FDA report from 1999 found that, even when not inhaled, DHA was reaching deeper skin levels and being absorbed into the body." 55 Even if all proper precautions are taken, DHA may still be absorbed through the human skin after a sunless tanning application.

The FDA has received reports from consumers who have experienced adverse effects associated with spray tanning, including: allergic reactions, rashes, itchiness, inflammation of the hair follicles, dry skin, coughing, dizziness, and fainting. ${ }^{56}$ Further research is necessary to investigate the specific causes of these symptoms. Consumers with nut allergies, however, should be particularly cautious of spray tanning. In October of 2012, a fifteen-year-old with a nut allergy, Alyssa Misemer of Platte City, Missouri, had a severe allergic reaction to a spray tan solution, and she later said "[r]ight when I found out that . . . the tan had walnut extract in it, I was terrified that I was going to die from it." 57 Consumer awareness of the ingredients applied

52 Eva Wittgenstein and Helen K. Berry, Reaction of Dihydroxyacetone (DHA) with Human Skin Callus and Amino Compounds, 36 J. INVEST. DERMATOL. 283 (1961), available at http://www.nature.com/jid/journal/v36/n4/pdf/jid196146a.pdf (discussing present studies "undertaken to investigate the chemical mechanism responsible for the 'tanning' phenomenon.").

53 Id. at 285.

54 Sylvia B. Hubbard, Spray Tans Linked to Lung Cancer, NewsMaX Health (Aug. 22, 2013, 5:19 PM), http://www.newsmaxhealth.com/Headline/spray-tans-fake-tans-lungcancer-dihydroxyacetone/2013/08/22/id/521824.

55 Levine, supra note 34.

56 Sunless Tanners Guidance, supra note 24.

57 Abby Eden, Teen Says Spray Tan Could Have Killed Her, Fox4KC.coM (Oct. 23, 2012), http://fox4kc.com/2012/10/23/teen-says- 
during the spray tan process is necessary to avoid foreseeable allergic or adverse reactions. At present, no such procedural or informative requirement exists in the realm of sunless tanning booths.

Allegations of allergic reactions to spray tanning solutions have even faced the U.S. courts. In 2012, Adam Kaufman went on trial for the alleged strangulation murder of his wife Eleanora Kaufman who was found dead in her home in 2007.58 Kaufman's defense attorneys argued that the deceased "had applied a spray-on tan earlier that resulted in a violent allergic reaction, causing fatal respiratory failure after she collapsed, her neck draped over the magazine rack." 59 Later, the defense attorneys argued, "Kaufman's wife died of an undiagnosed heart disease and a fall onto a magazine rack." 60 Kaufman was acquitted in his wife's death because "the jury did not think the state proved its murder case beyond a reasonable doubt." 61 This situation illustrates the potential result of a severe allergic reaction to a spray tan solution and furthers the notion that spray tan solutions should be more thoroughly investigated and regulated to adequately protect innocent and uninformed consumers.

\section{DHA has no Regulatory Status}

The National Institute of Occupational Safety and Health and the Occupational Safety and Health Administration have set no standards or guidelines for

spray-tan-could-have-killed-her/ (last visited July 6, 2013) (discussing that Misemer had previously been spray tanned at the same salon, but was not alerted to the change in solution during a subsequent application).

58 Spray Can Tan Defense Colors Murder Trial, CBS Miami (May 5, 2012, 3:30 PM), http://miami.cbslocal.com/2012/05/05/spray-can-tandefense-colors-murder-trial/.

$59 \quad$ Id.

60 Casey Glynn, South Fla. Developer Adam Kaufman Acquitted in Wife's 2007 Death, CBSNEws.COM (June 6, 2012, 1:46 PM), http://www.cbsnews.com/8301-504083_162-57448198-504083/south-fladeveloper-adam-kaufman-acquitted-in'wifes-2007-death/.

61 Id. 
occupational exposure to, or work place allowable levels of, DHA. 62 Likewise, DHA was not on the American Conference of Governmental Industrial Hygienists list of compounds for which recommendations for a threshold limit value or biological exposure index are made. ${ }^{63}$ While the Fair Packaging and Labeling Act (FPLA) authorizes the FDA to require ingredient declarations on products sold to consumers on a retail basis, FPLA does not apply to products used exclusively by professionals, such as those used in spray tanning booths. ${ }^{64}$ Thus, consumers cannot access information about the contents of spray tanning solutions, and may be unable to identify allergens in the substances.

\section{INITIAL GOVERNMENTAL RESPONSE TO INDOOR TANNING REGULATION}

Since the 1920s, countless Americans have been attentive to maintaining a "healthy" glow. 65 Early access to indoor UV tanning devices was virtually unrestricted. ${ }^{66}$ As consumers sought a tanned appearance, the government eventually responded by increasing indoor UV tanning legislation, particularly focused on decreasing youth access. ${ }^{67}$ However, despite the unknown risks associated with long-term exposure to sunless tanning solutions and the lack of investigatory science on the subject, both federal and state governments have failed to adequately regulate the spray tanning industry. This section discusses the history and background of indoor tanning regulation worldwide but focuses on the U.S.

\footnotetext{
62 DHA Summary, supra note 13.

63 Id.

64 Sunless Tanners Guidance, supra note 24.

65 Sheehan \& Lesher, supra note 2, at 1192.

66 See Busayo Obayan et al., Enacting Legislation to Restrict
} Youth Access to Tanning Beds: A Survey of Advocates and Sponsoring Legislators, 63 J. AM. ACAD. DERMATOL. 63 (2010) ("Between 1998 and 2007 there has been an increase in the attitude that tans enhance appearance and a corresponding increase in the number of tanning facilities, making tanning beds more accessible to youth.").

67 Id. 


\section{A. Governmental Response to Indoor UV Tanning}

Regulation of the UV tanning industry has evolved alongside increasing scientific discoveries associated with the risks of UV tanning practices. Despite evidence of serious human health hazards related to UV exposure, the U.S. government did not begin to regulate indoor UV tanning until the mid-1970s "due to numerous reported sunlamp related injuries." 68 The American Academy of Dermatology, the American Medical Association, the WHO, and other health organizations have since advocated for anti-tanning policies aimed at consumer protection. ${ }^{69}$ Since 2003, "youth access to indoor tanning has become increasingly restricted throughout the world as accumulating evidence demonstrated an association between melanoma and indoor tanning."70 While the U.S. federal government regulates tanning devices through the FDA, ${ }^{71}$ it has been unresponsive to efforts for more stringent "regulations of the indoor [UV] tanning industry at the federal level."72 However, a shifted focus by health groups on state and local levels has resulted in further regulation of the indoor UV tanning industry..$^{73}$

68 Michelle K. Pulley, Comment, Government Tan Lines: Examining the Reach and Effectiveness of Federal and State Efforts to Protect Consumers from the Dangers of Indoor Tanning, 36 PEPP. L. REV. 1161, 1171 (2009) (citing 21 C.F.R. $\$ 1040$ (2013)).

69 Id. at 1178-79 (citing Paul Vitello, Skin Cancer up Among Young; Tanning Salons Become Target, New YoRK TIMES, Aug. 14, 2006, at B1 http://query.nytimes.com/gst/fullpage.html?res= 9C03E1DC173EF937A2575BC0A9609C8B63 (discussing that health organizations "have labeled tanning beds as the health-peril equivalent of cigarettes.")).

70 As further evidence of the detrimental health effects of UV radiation, a fourteen-year Scandinavian study suggested that as "[c]ompared with nonusers of tanning beds, the risk of melanoma was 1.3 times greater for people who used tanning beds for 1 to 10 sessions, 1.8 times greater for people who used tanning beds for 11 to 24 sessions, and 2.7 times greater for people who used tanning beds more than 100 sessions." Pawlak, supra note 6, at 1009, 1011.

71 See 21 C.F.R. \$ 1040.20 (2013).

72 Pulley, supra note 68, at 1179 (citing 21 C.F.R. $\$ 1040.20$ ).

73 Id. at 1180 (citing Jennifer Saranow, States Crack Down on Indoor Tanning, WALL ST. J. (Jan. 26, 2005), http://online.wsj.com/ 
As of 2008, legislation intended to reduce consumer health risks of indoor tanning facilities had been enacted in twenty-eight U.S. states. ${ }^{74}$ A study reporting actual enforcement practices related to indoor tanning laws revealed data indicating, "routine annual inspections, which are a prerequisite for other enforcement activities such as levying penalties for violations, are not conducted in $64 \%$ of the cities." 75 As demonstrated in the American Medical Association's study, "legislation restricting all minors has a greater impact in reducing youth indoor tanning than legislation requiring only parental consent or parental accompaniment." 76 As of 2011, however, "[1] egislation banning access of high-risk groups to sunbeds has only been introduced in a limited number of jurisdictions worldwide, and there is to date only limited evidence available on compliance."77 Thus, mere evidence of a legislative response to limit access to indoor UV tanning may not be indicative of its effectiveness. Consumer awareness should also be promoted as a means to limit exposure.

In 2009, the WHO "reclassified all forms of sunlamps, tanning beds, and UV light as class 1 carcinogens, which are known to cause cancer in humans."78 In this way, the WHO enlightened indoor UV tanning consumers of the

article/0,,SB110669233656235821,00.html).

74 Joni A. Mayer et al., Enforcement of State Indoor Tanning Laws in the United States, 5 PREVENTING CHRONIC DISEASE, no. 4, 2008, at 1, available http://www.ncbi.nlm.nih.gov/pmc/articles/PMC2578791/pdf/PCD54A125. pdf.

75 Id. at 3.

76 Pawlak, supra note 6, at 1009.

77 Jennifer K. Makin et al., Compliance with Age and Skin Type Restrictions Following the Introduction of Indoor Tanning Legislation in Melbourne, Australia, 27 Photodermatology, Photolmmunology, AND PHOTOMEDicine 286, 291 (2011) ("In the United States, compliance with state laws restricting access for minors has been found to be less than optimal, potentially partly due to lack of enforcement.").

78 Pawlak, supra note 6, at 1007 (citing Position Statement on Indoor Tanning, AMERICAN ACADEMY OF DERMATOLOGY, http://www.aad.org/forms/policies/Uploads/PS/PS-

indoor\%20Tanning\%2011-16-09.pdf); Salynn Boyles, WHO: Tanning Beds Cause Cancer, WEBMD (July 28, 2009), http://www.webmd.com/ healthy-beauty/news/20090728/who-tanning-beds-cause-cancer. 
known risks associated with this practice. Legislatures also sought to provide enhanced protection to minors. 79 Awareness of the human health hazards associated with indoor UV tanning alone was not sufficient to shield adolescents from detrimental decisions. ${ }^{80}$ Specifically, "[t]he number of countries that had nationwide indoor tanning laws for youth [eighteen] years or younger increased from [two] countries (France and Brazil) in 2003 to [eleven] countries in 2011."81 In the U.S. alone, the number of states restricting youth access to indoor tanning increased from three states in 2003 to eleven states by $2011 .{ }^{82}$ Of the remaining thirty-nine states, only twenty-one states "require[d] parental consent or accompaniment for tanning bed use" at that time. ${ }^{83}$ Because most of this legislation focuses on the youth, it fails to adequately address issues associated with adult indoor UV tanning practices. One explanation is that legislators believe consumers have been adequately warned of the health risks associated with indoor UV tanning usage, and therefore adult rights should not be infringed. The same should be true for spray tanning practices, but it is not. Consumers are not adequately informed of the chemical ingredients in spray tanning solutions, nor are frequent spray-tanners aware of the uninvestigated nature of long-term human exposure to such products.

Under the FFDCA, UV tanning devices are currently regulated by the FDA as Class I medical devices, the most lightly regulated category. ${ }^{84}$ Perhaps the FDA regulates

79 See Mayer et al., supra note 74, at 1-5.

80 See id.

81 Pawlak, Restricting Access to Indoor Tanning, supra note 6, at 1008 ("These [eleven] countries are France, Spain, Portugal, Germany, Austria, Belgium, England. Whales, Northern Ireland, Scotland, and Brazil.").

82 Id. ("California increased the indoor tanning restriction to youth [eighteen] years or younger and became the first state in the United States to restrict indoor tanning to all minors.").

83 Id.

84 STAFF OF U.S. HOUSE OF REPRESENTATIVES COMM. ON ENERGY AND Commerce, 112 $2^{\text {th }}$ Cong., False AND Misleading Health INFORMATION PROVIDED TO TEENS BY THE INDOOR TANNING INDUSTRY: INVESTIGATIVE REPORT 7 (2012), available at 
this known carcinogen in the least stringent medical device category to avoid infringing upon consumers' freedom of choice; however, it seems that such devices should be more rigorously regulated as UV exposure carries a multitude of dangerous health risks. UV tanning beds "are subject to FDA's general controls for medical devices (including rules about good manufacturing practices, recordkeeping, reporting, adulteration, and misbranding) and performance standards specific to tanning beds." 85 These standards may not be enough to adequately protect consumers from the potential harms of this known carcinogen.

\section{B. Governmental Response to Indoor Sunless Tanning}

There is no federal-level regulation of the spray tanning industry. The FDA maintains, "firms and individuals who market cosmetics are responsible for assuring that the products they market are safe when used under labeled or customary conditions of use." 86 However, tanning salons are not effectively regulating spray tanning products, as the "vast majority of tanning salons contacted by Committee investigators provided false information about the serious risks of indoor tanning and made suspicious claims about the health benefits that indoor tanning provides." 87 While legislation was enacted to restrict indoor UV tanning throughout the world, the same has not been done for its sunless counterpart despite the unknown risks associated with human exposure to (and absorption of) spray tanning solutions.

http://democrats.energycommerce.house.gov/sites/default/files/document s/False-Health-Info-by-Indoor-Tanning-Industry-2012-2-1.pdf

[hereinafter U.S. House of Representatives Investigative Report] (discussing the limited federal oversight attributed to Class I devices including Band-Aids, rubber gloves, and tongue depressors, which present minimal potential harm to the user);_21 U.S.C. $\S 360$ c (2013) (effective July 9, 2012).

85 U.S. House of Representatives Investigative Report, supra note 84, at 7 (citing 21 U.S.C. $\$ 360 c(a)(1)(B)$ (2013) (effective July 9, 2012)).

86 Sunless Tanners Guidance, supra note 24.

84 , at 2 .

87 U.S. House of Representatives Investigative Report, supra note 


\section{CURRENT INDOOR TANNING REGULATIONS}

This section discusses current indoor tanning regulation in more detail, and it examines both federal and state regulation pertaining to the indoor tanning industry. In particular, this section highlights the differences between the regulation of indoor UV tanning and indoor spray tanning and suggests that more stringent regulations should be enacted to adequately protect consumers from the potential harms associated with indoor spray tanning practices. This section further suggests that additional research is necessary to determine whether spray tanning booths should be approved by the FDA, and it seeks to encourage enhanced consumer knowledge and protection concerning sunless tanning solutions, ingredients, and uninvestigated human health hazards.

\section{A. Federal Indoor Tanning Regulations}

In response to the growing concern about the long-term health risks associated with indoor tanning practices, 88 the FDA initially promulgated indoor tanning regulations over three decades ago; however, federal regulation of the indoor tanning industry has since expanded.89 While the majority of current indoor tanning regulation exists at the state

88 Pawlak, supra note 6, at 1006 ("Long-term health risks of indoor tanning are premature aging, immune suppression, cataract and other eye injuries, and skin cancers. Skin cancer is the most common cancer in the United States, and approximately [twenty-percent] of Americans will develop skin cancer in their lifetime.") (internal citations omitted).

89 See Sunlamp Products Performance Standard, 42 Fed. Reg. 65,189, 65,189 (Dec. 30, 1977) (codified at 21 C.F.R. $\S 1040.20$ (2013) (effective April 22, 2010); but see Eric Conroy, Master Sunshine: The Overzealous War on Indoor Tanning, SLATE (May 13, 2006, 7:47 AM ET), http://www.slate.com/articles/health_and_science/human_nature/ 2006/05/master_sunshine.single.html\#pagebreak_anchor_2 (Without guidance, technology can be dangerous, and it has been predicted that "[i]t won't be Congress that stops teens from cooking their skin. It'll be tanning sprays and lotions, which continue to improve in appearance, durability, and popularity. And guess who's going to lead the way? Salons."). 
level, 90 the federal government nevertheless plays an important role in protecting consumers. This sub-section highlights the important federal regulations pertaining to the tanning industry. It delves into the protections (or lack thereof) afforded to tanning consumers, including a discussion of the FFDCA's regulation of tanning devices and the Federal Trade Commission's (FTC) regulation of tanning advertisements. ${ }^{91}$ In addition, this sub-section addresses the following key concerns: the lack of consumer awareness and the effectiveness of the imposition of tanning taxes.

\section{The FDA: Regulating Color Additives and Tanning Devices Under the FFDCA}

The FDA's legal authority over cosmetics is different from other products regulated by the Agency. Cosmetic products and ingredients are not subject to FDA premarket approval authority, with the exception of color additives. ${ }^{92}$ The FDA regulates the color additive DHA as an external cosmetic product. ${ }^{93}$ The FDA requires that DHA "be safely used in amounts consistent with good manufacturing practice in externally applied drugs intended solely or in part to impart a color to the human body."94 DHA must also conform to identity and specification limitations required by the FDA.95 However, "[c]ertification of this color additive, [DHA], is not necessary for the protection of the public health and therefore batches thereof are exempt from the certification requirements of Section 721(c) of the Act." 96

90 See infra Section IV.B.

91 See 15 U.S.C. $\$ 41$ (2013) (effective May 24, 1950).

92 Sunless Tanners Guidance, supra note 24.

9321 C.F.R. $\$ 70.3 \mathrm{v}$ (2013); id. $\$ 73.2150$ (As a cosmetic product, DHA must be "applied only to external parts of the body and not to the lips or any body surface covered by mucous membrane.").

$94 \quad$ See id. $\S 73.1150(\mathrm{c})$.

95 See id. $\S 73.1150(\mathrm{a})$, (b).

96 See id. $§ 73.1150(\mathrm{e})$; see also Sunless Tanners Guidance, supra note 24 ("[R] egulations listing DHA as a color additive also require it to meet tight specifications, with strict limitations on impurities."); see 21 C.F.R. § 73.1150 . 
Because safety data to support the use of DHA in spray tanning facilities has not been submitted to the FDA for review and evaluation, "the use of DHA in 'tanning' booths as an all-over spray has not been approved by the FDA." 97 Although this statement is available on the FDA's website, it may not be largely known by consumers in the U.S. and worldwide. Thus, it is important for federal and state governments, as well as national and local health authorities, to adequately inform the public of the unknown risks associated with regular spray tanning booth use.

Under the FFDCA, UV tanning beds and tanning lamps are regulated as medical devices. ${ }^{98}$ As defined within the FFDCA, the term "device" includes any instrument that is "intended to affect the structure or any function of the body of man . . . ."99 Because the UV rays emitted from the tanning bed lamps alter the human skin by producing a tan, indoor UV tanning devices necessarily fall within this definition. Likewise, under the electronic product radiation control provisions of the FFDCA, the FDA maintains the authority to regulate UV tanning devices as radiationemitting medical electronic products. ${ }^{100}$

For purposes of radiological health, the FDA sets the performance standards for light-emitting products, including "[s]unlamp products and [UV] lamps intended for use in sunlamp products." 101 The FDA regulation of UV tanning devices involves performance standards, irradiance ratio limits, a timer system, control for termination of radiation emission, safety precautions such as the use of protective eyewear, label requirements, instructions to be provided to users, and compliance tests. ${ }^{102}$ Much of the

97 Sunless Tanners Guidance, supra note 24.

9821 U.S.C. $\S 321(\mathrm{~h})$ (2013) (effective June 22, 2009).

$99 \quad$ See id. $\S 321(\mathrm{~h})(3)$.

100 U.S. Dep't of Health and Human Servs., Radiation-Emitting Products: Summary of the Electronic Product Radiation Control Provisions of the Federal Food, Drug, and Cosmetic Act, U.S. FooD AND DRUG ADMIN., http://www.fda.gov/radiation-emittingproducts/ electronicproductradiationcontrolprogram/lawsandregulations/ucm 1181 56.htm (last updated Mar. 1, 2010); 21 U.S.C. $\$ \S 360$ hh-360ss.

10121 C.F.R. $\$ 1040.20$.

102 Id. 
FDA's regulation of UV tanning devices focuses upon the "[1]abels for sunlamp products," which must contain: a warning statement, recommended exposure positions, directions for achieving the recommended exposure, a recommended exposure schedule, a timeframe of expected results, and a designation of the UV lamp within the product. ${ }^{103}$ UV lamps must have "a label which contains: [t]he words Sunlamp--DANGER--Ultraviolet radiation. Follow instructions."104 All UV tanning device labels must meet stringent specifications whereby any label "shall be permanently affixed or inscribed on an exterior surface of the product ... so as to be legible and readily accessible to view by the person being exposed immediately before the use of the product."105

Under the FFDCA, the FDA must classify "devices intended for human use" in one of three categories. ${ }^{106}$ Class I devices are subject to general controls, whereas Class II devices are subject to special controls and

103 See id. $\$ 1040.20(\mathrm{~d})(1)(\mathrm{i})-(\mathrm{vi})$. The warning statement must include the following:

DANGER--Ultraviolet radiation. Follow instructions. Avoid overexposure. As with natural sunlight, overexposure can cause eye and skin injury and allergic reactions. Repeated exposure may cause premature aging of the skin and skin cancer. WEAR PROTECTIVE EYEWEAR; FAILURE TO MAY RESULT IN SEVERE BURNS OR LONG-TERM INJURY TO THE EYES. Medications or cosmetics may increase your sensitivity to the ultraviolet radiation. Consult physician before using sunlamp if you are using medications or have a history of skin problems or believe yourself especially sensitive to sunlight. If you do not tan in the sun, you are unlikely to tan from the use of this product.

Id. $\$ 1040.20(\mathrm{~d})(1)(\mathrm{i})$.

104 See id. $\$ 1040.20(\mathrm{~d})(2)(\mathrm{i})$. UV lamp labels must also include the model identification as well as the words "[u]se ONLY in fixture equipped with a timer." Id. $\S 1040.20(\mathrm{~d})(2)(\mathrm{ii})$-(iii).

105 See id. $\$ 1040.20(\mathrm{~d})(3)(\mathrm{i})$.

10621 U.S.C. $\S 360$ c (2013) (effective July 9, 2012). 
cannot be classified as a [C]lass I device because the general controls by themselves are insufficient to provide reasonable assurance of the safety and effectiveness of the device, and for which there is insufficient information to establish special controls to provide such assurance, including the promulgation of performance standards, postmarket surveillance, patient registries, development and dissemination of guidelines . . . recommendations, and other appropriate actions . . . ${ }^{107}$

Class III devices require premarket approval because "insufficient information exists to determine that the application of general controls are sufficient to provide reasonable assurance of the safety and effectiveness of the device," and because "insufficient information exists to determine that the special controls described in subparagraph (B) would provide reasonable assurance of its safety and effectiveness."108 Furthermore, Class III devices are either "purported or represented to be for a use in supporting or sustaining human life" or "presents a potential unreasonable risk of illness or injury."109 Indoor UV tanning devices are regulated under Section 201(h)(3) of the FFDCA as Class I medical devices, the least stringent regulatory category. ${ }^{110}$ At present, spray tanning devices are not regulated under the FFDCA.

While it is within the FDA's authority to regulate the performance standards of UV tanning devices, the FDA is also authorized by the FFDCA to restrict the sale, distribution, or use of any such device.111 Because of a device's "potentiality for harmful effect or the collateral measures necessary to its use," and if "there cannot otherwise be reasonable assurance of its safety and

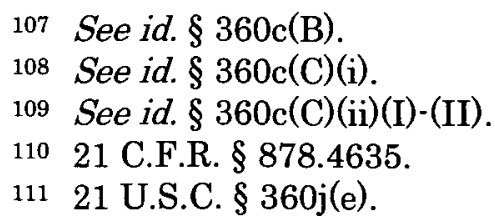


effectiveness," the FDA may restrict the use of a device through regulation. ${ }^{112}$ Similarly, the FFDCA gives the FDA the authority to ban a device intended for human use if it "presents substantial deception or an unreasonable and substantial risk of illness or injury." 113 Because it is within the FDA's power to regulate, restrict, and ban any device regulated within the FFDCA, the FDA may consequently regulate UV tanning beds.

Unlike the UV tanning devices regulated under the FFDCA as Class I medical devices, the FDA does not regulate spray tanning devices. The FDA merely cautions consumers against the use of spray tanning booths on its website. ${ }^{114}$ Nevertheless, the FDA requires "[t]he labeling of suntanning preparations that do not contain a sunscreen ingredient." 115 The CFR defines the term "suntanning preparations" to include:

gels, creams, liquids, and other topical products that are intended to provide cosmetic effects on the skin... . or to give the appearance of a tan by imparting color to the skin through the application of approved color additives (e.g., dihydroxyacetone) without the need for exposure to UV radiation. ${ }^{116}$

Although sunless tanning products and spray tanning devices must contain appropriate warnings as required by the FDA, there is no current federal regulation of spray tanning booths or the solutions emitted therefrom. Instead, the FDA advises consumers to ask several "questions when considering commercial facilities where DHA is applied by spraying or misting." 117 According to the FDA, if consumers are not sheltered from DHA exposure

\footnotetext{
112 See id. $\S 360 \mathrm{j}(\mathrm{e})(1)(\mathrm{B})$.

113 See id. $\S 360 \mathrm{f}(\mathrm{a})(1)$.

114 Sunless Tanners Guidance, supra note 24.

11521 C.F.R. $\$ 740.19$.

$116 I d$.

117 Sunless Tanners Guidance, supra note 24.
} 
in the entire area of the eyes, in addition to the eyes themselves, ... the lips and all parts of the body covered by mucous membrane, ... [and] internal exposure caused by inhaling or ingesting the product ... the consumer is not protected from the unapproved use of this color additive. ${ }^{118}$

The FDA instead places the responsibility for the safety of spray tanning booths on salons as well as state and local health authorities. ${ }^{119}$ Although spray tanning booths have not been authorized for consumer use, the FDA suggests that consumers may safely apply sunless tanning products sold in retail stores (such as creams and lotions) because "DHA is approved for external application to the human body, which is the way these products are intended to be used." 120

Since DHA is approved by the FDA to impart color to the human body in specified methods and not as an all-over spray, confusion may arise amongst consumers as to the safety of sunless tanning products. Countless consumers may be operating under the assumption that because the FDA has approved DHA under limited circumstances, it must be safe to utilize spray tanning booths. Due to consumer confusion and the possibility of unknown health risks associated with DHA exposure, more stringent regulations must be established to protect and educate the general public, consumers, and salon professionals.

\section{The FTC: Regulating Advertising Claims by the Indoor Tanning Industry}

While the FDA regulates UV tanning devices and color additives, the FTC regulates "the content of advertising

118 Id.

119 Id.

120 Id. ("Consumers can easily avoid inhaling [DHA-containing creams or lotions] or applying them to the area of the eye or mucous membrane."). 
claims made by the indoor tanning industry."121 Under the Federal Trade Commission Act (FTCA), the FTC has the authority to regulate advertising in general. ${ }^{122}$ The FTCA mandates, "[a]dvertising must be truthful and nondeceptive; [a]dvertisers must have evidence to back up their claims; and [a]dvertisements cannot be unfair." 123 According to a 1983 FTC Policy Statement on Deception, an advertisement is unlawfully deceptive if it contains a statement or omits information that "[i]s likely to mislead consumers acting reasonably under the circumstances; and [i] 'material' - that is, important to a consumer's decision to buy or use the product." 124 Specifically, the FTCA prohibits "any person, partnership, or corporation to disseminate, or cause to be disseminated, any false advertisement."125 It is unlawful to falsely advertise "[b]y any means, for the purpose of inducing, or which is likely to induce, directly or indirectly, the purchase in or having an effect upon commerce, of food, drugs, devices, services, or cosmetics."126 Sunless tanning industry advertisements are subject to FTC regulation under the FTCA.

Because the FTC pays closest attention to advertisements "that make claims about health or safety" or "that make claims that consumers would have trouble evaluating for themselves," the FTC implies that it more stringently monitors advertisements made by the tanning industry. ${ }^{127}$ In fact, when the Indoor Tanning Association (ITA) "launched an advertising campaign designed to

121 Pulley, supra note 68, at 1183; see Federal Trade Commission Act of 1950 (FTCA), 15 U.S.C. $\$ \S 41-52$ (2013) (effective May 24, 1950).

122 Federal Trade Commission Act of 1950 (FTCA), 15 U.S.C. $\S \S 41^{-}$ 52.

123 Bureau of Consumer Prot. Bus. Ctr., Advertising FAQ's: $A$ Guide for Small Businesses, Federal Trade Commission (Apr. 2001), http://business.ftc.gov/documents/bus35-advertising-faqs-guide-smallbusiness; see Pulley, supra note 68, at 1187 (discussing the FTC regulating advertising claims by the indoor UV tanning industry).

124 Pulley, supra note 68, at 1187 (citing FTC Policy Statement on Deception (Oct. 14, 1983), http://www.ftc.gov/bcp/policystmt/addecept.htm).

12515 U.S.C. $\$ 52(\mathrm{a})$.

126 Id. $\S 52(\mathrm{a})(2)$.

127 Bureau of Consumer Prot. Bus. Ctr., supra note 123. 
portray indoor tanning as safe and beneficial" in March of 2008, the FTC charged the ITA "with making false health and safety claims about indoor tanning."128 The subsequent 2010 settlement agreement between the FTC and the ITA prohibits the ITA from making misrepresentations about the indoor tanning industry, from misrepresenting any tests and studies, from providing deceptive advertisements to members, and it also "requires that future association ads that make safety or health benefits claims for indoor tanning may not be misleading and must be substantiated." 129 Likewise, to increase consumer awareness of the myths and reality of UV tanning, the FTC published consumer information regarding the UV tanning industry in January of $2010 .{ }^{130}$

While the FTC purports to investigate "false, misleading, and deceptive advertising claims about [tanning] devices," it makes no mention of regulating spray tanning advertisements. ${ }^{131}$ FTC regulation has afforded some consumer protection by disallowing unsubstantiated health and safety claims about indoor UV tanning. For this reason, the FTC should also regulate sunless tanning industry advertisements. Because "[n]o U.S. government agency recommends the use of indoor tanning equipment," the FTC must further seek to dispel the notion that UV or sunless indoor tanning has been "approved by the government." 132 As advertisements so greatly affect consumers' opinions about appearance and skin color, the FTC must help to protect consumers from the potential harms associated with frequent indoor sunless tanning use

128 Indoor Tanning Association Settles FTC Charges That it Deceived Consumers About Skin Cancer Risks from Tanning, FEDERAL TRADE COMMISSION (Jan. 26, 2010), http://www.ftc.gov/opa/2010/01/ tanning.shtm.

129 Id.

130 Consumer Information: Indoor Tanning, FEDERAL TRADE COMMISSION (Jan. 2010), http://www.consumer.ftc.gov/articles/0129indoor-tanning (dispelling false claims commonly made about indoor UV tanning).

131 Id.

$132 I d$ 
unless or until the safety of spray tanning devices is substantiated.

\section{Tanning Accountability and Notification Act of 2007 (TAN Act)}

As part of the Food and Drug Administration Amendments Act, the Tanning Accountability and Notification Act of 2007 (TAN Act) mandated that the FDA review the warning labels affixed to indoor tanning equipment. ${ }^{133}$ The TAN Act directs the FDA to continue to determine whether tanning bed labels effectively inform consumers about the risks associated with frequent use, and if considered ineffective, to reconsider the label language. ${ }^{134}$ The TAN Act also provides significant benefits for the development and use of medical products and ensures that the FDA will have the resources necessary to conduct comprehensive new device reviews. ${ }^{135}$

In compliance with the TAN Act and after determining that the current labels for indoor tanning devices did not effectively communicate the risks associated with indoor tanning, the FDA reported such findings to Congress in December of 2008.136 To limit both the amount of UV rays emitted by tanning beds and the amount of consumer exposure time, U.S. House Representative Carolyn Maloney (D-NY) introduced the "Tanning Bed Cancer Control Act of 2011" (TBCCA). 137 The TBCCA was undoubtedly a response to the FDA findings following the enactment of the

133 Food and Drug Administration Amendments Act of 2007, Pub. L. No. 110-085, 121 Stat. 823 (codified as amended in scattered sections of 21 U.S.C. $\S 301$; U.S. Dep't of Health and Human Servs., Regulatory Information: Food and Drug Administration Amendments Act (FDAAA) of 2007, U.S. FOOD AND DRUG ADMIN., http://www.fda.gov/

regulatoryinformation/legislation/federalfooddrugandcosmeticactfdcact/s ignificantamendmentstothefdcact/foodanddrugadministrationamendme ntsactof2007/default.htm [hereinafter FDAAA Regulatory Information] (last visited Aug. 25, 2013).

134 See Knapp , supra note 10 , at 30 (citing 121 Stat. 823).

135 FDAAA Regulatory Information, supra note 133.

136 Tanning Bed Cancer Control Act of 2011, H.R. 1676, 112th Cong. (2011). 
TAN Act "to help prevent the occurrence of skin cancer resulting from the routine use of UV tanning lamps by imposing more stringent controls on the use of such devices."138 The TBCCA proposes to complete a study on the performance standards established under the FFDCA for UV tanning lamps to examine the effectiveness of such standards, ${ }^{139}$ and to revise such performance standards and labeling of UV tanning devices as necessary following the study. ${ }^{140}$ Though not yet enacted, the TBCCA more effectively protects consumers from the harms of UVemitting tanning beds.

\section{Tanning Tax}

While the Patient Protection and Affordable Care Act imposes a tax of ten percent on the amount paid for tanning services (effective July 1, 2010), the use of spray tanning devices is not included in this taxation scheme. ${ }^{141}$ Under the Internal Revenue Code, the ten percent tax applies only to any indoor tanning services "employing any electronic product designed to incorporate [one (1)] or more [UV] lamps and intended for the irradiation of an individual by [UV] radiations, with wavelengths in air between 200 and 400 nanometers, to induce skin tanning." 142 Perhaps as knowledge increases about the uninvestigated effects of frequent spray tanning on the human body, this tanning tax will be extended to spray tanning devices as well. If the government finds the tanning tax to be lucrative, it may

138 Id.

13921 U.S.C. $\S 360 d$ (2013) effective July 9, 2012).

140 H.R. 1676.

141 Patient Protection and Affordable Care Act, Pub. L. No. 111-148, 124 Stat. 119 (2010) (codified at 42 U.S.C. $§ 18001$ (2010)); see Knapp, supra note 10 , at $31-32$ (discussing the imposition of a tanning tax on indoor UV tanning salons and comparing it to "[t]he data on the effectiveness of the cigarette tax [which] supports the argument that sin taxes reduce activity levels.") (citing Ann Boonn, Raising Cigarette Taxes Reduces Smoking, Especially Among Kids (and the Cigarette Companies Know It), CAMPAIGN FOR TOBACCO-Free KIDS (Oct. 11, 2012), http://www.tobaccofreekids.org/research/factsheets/pdf/0146.pdf).

14226 U.S.C. $\$ 5000 B(b)(1)(2013)$. 
extend the tax to spray tanning simply to increase revenue. Though a tanning tax may not lead directly to greater consumer protection, the added cost may deter some consumers from tanning and may assist the government in funding tanning regulation programs. ${ }^{143}$ Nevertheless, if the tanning tax is absorbed by the industry and is not passed on to the customers, "it is unlikely to dissuade frequent tanners or result in a scarcity of tanning, [and] the tax by itself is unlikely to substantially reduce activity levels." 144

\section{B. State Tanning Regulations}

While a federal-level regulatory scheme on indoor tanning would likely have the most far-reaching impact, in the absence of federal oversight current indoor tanning legislation is primarily drafted and enforced by each state. ${ }^{145}$ Apprehensive about the lack of federal regulation, many state legislatures have enacted tanning regulations pertaining to a number of areas including equipment standards, facility-related regulations, enforcement issues, and access to tanning services. ${ }^{146}$ Although tanning regulations vary by state, these consumer protections reflect a restrictive trend on the use of indoor tanning by minors. ${ }^{147}$

143 Pulley, supra note 68, at 1222 (discussing a tanning tax as a possible alternative to traditional indoor tanning regulation).

144 Knapp, supra note 10 , at 32 .

145 Lucy L. Chen \& Steven Q. Wang, Post-California Tanning Ban: A Brief Updated on Current Youth Access Laws, 148 ARCH. DERMATOL. 1071, 1071 (2012).

$146 I d$.

1472013 Indoor Tanning Legislation: 2013 State by State Comparison, AIM AT MELANOMA, http://www.aimatmelanoma.org/en/ aim-for-a-cure/legislative-accomplishments-in-melanoma/2013-indoortanning.html (last updated Aug. 2013) [hereinafter 2013 State Comparison: Indoor Tanning Legislation] (describing state bills and listing state law indoor tanning restrictions for minors); Indoor Tanning Restrictions for Minors - A State-by-State Comparison, NAT'L CONF. OF ST. LEGISLATURES, http://www.ncsl.org/issues-research/health/indoortanning-restrictions.aspx (last updated Aug. 2013) [hereinafter Tanning Restrictions for Minors: State Comparison] (listing indoor tanning regulations for beds, booths, and sunlamps). 
This subsection highlights the important state regulations relating to the indoor tanning industry, and it elaborates on state UV tanning regulations in addition to state spray tanning regulations by comparing the state protections afforded to tanning consumers. In addition, this subsection addresses Indiana's efforts to protect minors from spray tanning practices.

\section{State Indoor UV Tanning Regulations}

A majority of the states regulate the indoor tanning industry beyond the minimal federal regulations, applying specific prohibitions on UV tanning bed usage. ${ }^{148}$ While thirty-two states regulate indoor UV tanning for minors, ${ }^{149}$

1482013 State Comparison: Indoor Tanning Legislation, supra note 147 (listing thirty-four state statutes restricting indoor tanning for minors and fourteen state bill descriptions); Tanning Restrictions for Minors: State Comparison, supra note 147 (listing thirteen states that have introduced indoor tanning legislation in 2013).

149 See ARIZ. ADMIN. CODE $\S$ R12-1-1414(A)(2) (2013) (tanning equipment operators); ARK. CODE ANN. § 20-27-2202 (2009) (consent required); CAL. BUS. AND PROF. CODE $§ 22706(b)(3)$ (2013) (operating regulations; customer acknowledgement of warnings; use of facilities by minors); CONN. GEN. STAT. $§ 19 \mathrm{a}-232$ (2012) (parental consent for minors); DEL. CODE ANN. tit. 16, $\S 3003 D$ (2013) (restrictions on use by minors); FLA. STAT. $§ 381.89(7)$ (2013) (regulation of tanning facilities); GA. CODE ANN. $\S 31-38-8$ (b) (2013) (use of tanning equipment by minors); ILL. ADMIN. CODE tit. 77, § 795.190(c) (2013) (records); IND. CODE $\S 25-8-15.4-15,-16$ (2013) (presence of parent or guardian; signature of parent or guardian on written statement); KY. REV. STAT. ANN. § 217.922 (West 2013) (consent required for minor using tanning device or facility); LA. REV. STAT. ANN. § 40:2714(E) (2013) (information provided to consumer); 10-144 DEPT. OF HUMAN SERVICES ch. 223 $12 \mathrm{~A}(3)(\mathrm{f})$ (effective Mar. 1, 1991) (rules relating to tanning facilities); MD. CODE ANN., HEALTH-GEN. \$20-106 (effective Oct. 1, 2008) (use of tanning facilities by minors); MASS. GEN. LAWS ch. 111, § 211 (2013) (minors; parental consent; accompaniment by parent or guardian); MICH. COMP. LAWS $\S 333.13405(2)$ (effective Dec. 23, 2008) (use of tanning devices); MINN. STAT. $\S 325 \mathrm{H} .08$ (2012) (consent required); MISS. CODE ANN. $\S 41-115-1$ (2013) (use of tanning facilities by minor; parental presence; and consent); N.H. REV. STAT. ANN. § 313-A:31 (2013) (tanning of minors); N.J. STAT. ANN. § 26:2D-82.1 (effective June 29, 2012) (minors, prohibitions and restrictions upon facility usage, penalties); N.Y. PUBLIC HEALTH LAW $\S 3555$ (Consol. 2013) (restrictions 
only eighteen states "require operators to limit exposure time to manufacturers' recommendations and provide eye protection." 150 Nonetheless, countless individuals, both minors and adults, continue to frequent tanning salons and the American Cancer Society "estimates 76,000 new cases and nearly 9,200 deaths from melanoma in 2012."151

On January 1, 2012, California responded to the growing concern of the harmful effects of regular UV exposure to the human body, acting as the first state in the nation to ban use of UV indoor tanning beds for all minors less than eighteen years of age.152 Other states have since banned the use of indoor UV tanning beds by children under the age of fourteen. ${ }^{153}$ Some states have responded by requiring parental accompaniment for minors to use UV tanning

on the use of UV radiation devices); N.C. GEN. STAT. $§ 104 \mathrm{E}-9.1$ (a)(2) (2013) (restrictions on use and operation of tanning equipment); N.D. CENT. CoDE § 23-39-05(1)(a) (effective Aug. 1, 2007) (duties); OHIO ADMIN. CODE $§ 4713-19-09$ (2013) (records keeping); OR. ADMIN. R. 333119-0090(2) (2013) (protection of consumers); R.I. GEN. LAWS $\S 23-68$ 4(6) (effective Jan. 1, 2013) (safety standards established); TENN. CODE ANN. § 68-117-104(b)(3) (2013) (duties); TEX. HEALTH \& SAFETY CODE ANN. $\S 145.008$ (West 2013) (operational requirements); UTAH CODE ANN. $\S 26-15-13$ (West 2013) (regulation of tanning facilities); VT. STAT. ANN. tit. 18, § 1513(c) (effective July 1, 2012) (tanning facilities, minors, penalty); VA. CODE ANN. §59.1-310.3(B) (effective July 1, 2007) (notice to customer, liability); WIS. STAT. $§ 255.08$ (2013) (tanning facilities); WYo. STAT. ANN. § 14-3-108 (2013) (effective July 1, 2010) (use of UV tanning devices by persons who have not reached the age of majority).

150 Tanning Restrictions for Minors: State Comparison, supra note 147.

151 Id.

152 CAL. Bus. \& PRof. CODE $\S \S 22706,2241.3$ (2013) (effective Jan. 1, 2012). Vermont was the second state to pass similar legislation banning the use of UV tanning beds by minors under eighteen, which subjects tanning facilities and operators to civil penalties up to $\$ 500.00$ per offense. See Chen \& Wang, supra note 145, at 1071 (discussing the current status of tanning access restrictions and describing the challenges in the legislative path to "ban the tan.").

1532013 State Comparison: Indoor Tanning Legislation, supra note 147 (listing Delaware, Georgia, Illinois, Maine, New Jersey, New York (prohibiting minors under seventeen), North Carolina (prohibiting children under thirteen), Texas (prohibiting minors under sixteen-anda-half), Vermont (prohibiting minors under eighteen), and Wyoming (banning anyone under sixteen) as prohibiting children under fourteen from using UV tanning beds). 
beds, 154 while other states mandate written parental permission. 155 Most states, however, employ mixed or multiple UV tanning restrictions on minors but have no such restrictions for adults aged eighteen and above. ${ }^{156}$ In fact, Arizona goes so far as to require that public schools educate minors about the risks of developing skin cancer. ${ }^{157}$

Though no uniform indoor tanning legislation has been adopted amongst the states, ${ }^{158}$ some states have enacted gap-filling statutes to regulate aspects of UV tanning not covered by the FDA or the FTC. ${ }^{159}$ State efforts to regulate

154 Id. (citing Florida, Indiana, Kentucky, Louisiana, Maine, Massachusetts, Michigan, Mississippi, New Hampshire, North Dakota, Tennessee, Utah, and Wyoming as states that require parental or guardian accompaniment for minors under a certain age (generally thirteen to eighteen) to utilize indoor UV tanning beds).

155 Id. (citing Arkansas, Arizona, Connecticut, Delaware, Florida, Georgia, Illinois, Indiana, Kentucky, Louisiana, Maine, Maryland, Massachusetts, Michigan, Minnesota, Mississippi, New Hampshire, New Jersey, North Carolina, North Dakota, Ohio, Oregon, Rhode Island, South Carolina, Tennessee, Texas, Utah, Virginia, and Wyoming as requiring written parental or guardian consent authorizing the minor to use UV tanning beds).

156 Tanning Restrictions for Minors: State Comparison, supra note 147 (listing Delaware, Florida, Illinois, Indiana, Kentucky, Louisiana, Maine, Massachusetts, Mississippi, New Hampshire, New Jersey, New York, North Carolina, North Dakota, Rhode Island, Tennessee, Texas, Utah, and Wyoming as employing a combination of UV tanning restrictions on minors).

157 ARIZ. REV. STAT. ANN. § 15-718 (2012) ("All public schools shall incorporate instruction into the existing curricula in the common school grades on skin cancer prevention ... ."); see Tanning Restrictions for Minors: State Comparison, supra note 147.

158 Tanning Restrictions for Minors: State Comparison, supra note 147 (while some states have banned indoor UV tanning for minors of varying ages, others require parental accompaniment, parental permission, or impose no known state-wide restriction at all); see supra note 157.

159 Some states regulate the business aspects of indoor tanning, such as licensing, initial and annual fees, sanitation guidelines, inspections, record-keeping standards, and more. See, e.g., FLA. ADMIN. CODE ANN. r. 64E-17.004 (2013) (operation and training); id. r. 64E17.005 (sanitation); id. r. 64E-17.006 (license and fees); id. r. 64E17.007 (inspection, enforcement, and penalties); see IND. CODE $\$ 25-8$ 15.4-5 (2013) (necessity for license); id. $\S 25-8-15.4-6$ (license requirements); id. § 25-8-15.4-7 (contents of license application); id. $\S$ 
the tanning industry include mandated training for tanning bed operators, 160 written notice and other warning requirements, ${ }^{161}$ and implementation of penalties for noncompliance. ${ }^{162}$ Nevertheless, challenges still remain and despite this progress, the current legislation is not strong enough to protect consumers from the dangers of tanning. ${ }^{163}$

Although a majority of the states have sought to enhance consumer protection, salon compliance and consumer awareness have been difficult, as tanning regulations vary by state and may be hard to locate. ${ }^{164}$ Whether the protections afforded by state-level regulations are aimed at protecting consumers, reducing incidents of skin cancer, or making indoor UV tanning safer, these efforts will only be effective to the extent of regulatory compliance. ${ }^{165}$ The lack

25-8-15.4-14 (duties of operator); id. $\$ 25-8-15.4-17$ (protective eyewear); id. $\S 25 \cdot 8 \cdot 15.4-19$ (inspections); id. $\S ~ 25-8-15.4-24$ (civil penalties); 820 IND. ADMIN. CODE $\S 5-1-32$ (2013) (record-keeping requirements); see Pulley, supra note 68, at 1190-98 (discussing that "[m] any states also regulate indoor [UV] tanning in areas that are not covered by the FDA or the FTC.").

160 See Fla. Admin. Code. ANN. r. 64E-17.003 (2009); 210 ILL. COMP. STAT. 145/25 (2012); ILL. ADMIN. CODE tit. $77 \S 795.180$ (2013); 820 IND. ADMIN. CODE 5-1-34 (2013); OR. ADMIN. R. 333-119-0080(1), (3) (2012); TENN. CODE $§ 68-117-104(\mathrm{a})(1)$ (2011); VA. CODE $\S 59.1 \cdot 310.5(\mathrm{~A})$ (2013) (effective July 1, 2007)); see Pulley, supra note 68, at 1194.

161 Pulley, supra note 68, at 1194 ("This requirement is different from the FDA warning requirement because that warning requirement only applies to labels affixed on the tanning devices.") (citing 21 C.F.R. $\S$ 1040.20(d) (2008); CAL. BUS. \& PROF. CODE $§ 22706$ (2012); Fla. STAT. ANN. $\$ 381.89(4)(\mathrm{a})$ (West 2004); IlıL COMP. STAT. ANN. 145/25(f) (West 2007); IOWA CODE ANN. § 136D.4.2 (West 2007); TEX. HEALTH \& SAFETY CODE ANN. $\S 145.005(\mathrm{a})(1)-(7)$ (West 2001)).

162 Id. at 1195 (citing CAL. BUS. \& PROF. CODE $\S 22708$ (2005); FLA. STAT. ANN. § 381.89(9)-(10) (West 2004); IOWA CODE ANN. § 136D.8 (2012); KAN. STAT. ANN. § 65-1925(d) (West 2013); Wis. STAT. ANN. § 255.08(13)-(15) (West 2013)); see Chen \& Wang, supra note 145, at 1071 ("The legislation pertains to a number of areas, such as equipment standards, facility and operator-related regulations, enforcement and legal issues, and minors' access to tanning services.").

163 Chen \& Wang, supra note 145 , at 1071 (internal citation omitted).

164 See 2013 State Comparison: Indoor Tanning Legislation, supra note 147.

165 Pulley, supra note 68, at 1197 (discussing issues with state-level indoor UV tanning regulations). 
of uniform enforcement within the states, with "low rates of citations and inspections contributing to noncompliance," must be improved for the regulations to function. ${ }^{166}$ Effective tanning bed legislation must be enacted, enforced, and incrementally implemented to protect consumers by reducing exposure to UV light and incidents of melanoma. ${ }^{167}$

\section{State Indoor Spray Tanning Regulations}

There is a lack of both state and federal oversight of the sunless tanning industry, with no regulation of spray tanning booths. ${ }^{168}$ Although the federal government has addressed safety issues associated with UV tanning bed use, it places the burden on the states to more effectively protect consumers through state-level regulation. 169 Likewise, the FDA has explicitly passed the burden on to state and local health authorities to regulate spray tanning facilities. ${ }^{170}$ While the FDA retains the authority to take action against firms and individuals who violate the law, the FDA maintains "it is generally the responsibility of local and state health authorities" to monitor the practice of administering cosmetic products, including the use of spray tanning booths, by professionals. ${ }^{171}$ For this reason, the development of uniform indoor tanning industry guidelines regarding unapproved exposures to spray tanning products should be a priority for the states in protecting consumers

166 Chen \& Wang, supra note 145 , at 1071.

167 Obayan, supra note 66, at 63 ("Barriers to [the] passage of tanning bed legislation can potentially be surmounted with advice to advocates and coordinated efforts by multiple organizations.").

$168 \mathrm{Fu}$ et al., supra note 11, at 710 ("Despite this lack of federal or state oversight ... the National Tanning Training Institute has begun to advertise a sunless tanning certification course.") (internal citation omitted).

169 See supra Section IV. B. 1.

170 Fu et al., supra note 11 , at 710 ("[N]o formal federal guidelines have been issued regarding the regulation of commercial establishments that offer sunless tanning booth services.").

171 Sunless Tanners Guidance, supra note 24. 
from the uninvestigated effects of continued exposure to sunless tanning solutions.

Consumers generally perceive spray tanning as a safer method of achieving a tanned appearance. ${ }^{172}$ Nevertheless, no long-term human studies have been conducted to examine the health effects of frequent spray tan exposure. ${ }^{173}$ For this reason, states should enact spray tanning legislation adding protective provisions to the already-existing indoor UV tanning bed regulations. ${ }^{174}$ Before continued endorsements are made of the spray tanning booth, further investigations are needed to evaluate the safety and health implications of continued human use. Until such time, the states must take action and regulate this industry to adequately protect consumers from the unknown, under-investigated effects of regular spray tan exposure.

\section{Indiana Spray Tanning Regulations}

Indiana has imposed statutory authority over operators of indoor tanning facilities limited to the regulation of UV tanning products. ${ }^{175}$ As defined within the Indiana Code, a "tanning device" does not presently include a spray tanning booth. ${ }^{176}$ While the Indiana Code mentions the use of protective eyewear, it does not discuss nose plugs or other protective measures that would be useful during spray tan application. ${ }^{177}$ Indiana, however, is one of the first states to attempt to establish regulations for the use of sunless

172 Vilma E. Cokkinides et al., Use of Sunless Tanning Products Among Adolescents Aged 11 to 18 Years, 146 ARCH. DERMATOL. 987, 991 (2010) ("[T]his study found that approximately [one] in [ten] US adolescents uses sunless tanning products and that many users perceive sunless tanning as a safer way to tan than suntanning or indoor tanning."). An "increased awareness of the medical and cosmetic effects of UV radiation coupled with improved sunless tanning products are promoting the rapid growth of a sunless tanning industry." Fu et al., supra note 11 , at 706 .

173 Levine, supra note 34.

174 See, e.g., supra note 154.

175 IND. CODE $\S \S 25-8-15.4-1-25 \cdot 8-15.4-3$ (2013).

176 Id. $\S 25-8-15.4-3$.

177 Id. $\S 25-8-15.4-17$. 
tanning booths by minors. ${ }^{178}$ Conversely, some states specifically exclude the regulation of spray tan application. ${ }^{179}$

Indiana House Bill 1115 was introduced on January 6, 2012 requiring anyone under eighteen to have the written approval of a parent or guardian to be spray-tanned. ${ }^{180}$ The votes have not yet been cast on this bill. ${ }^{181}$ This legislation is much like the current Indiana law that requires parental

178 H.R. 1115, 117th Gen. Assemb., 2d Reg. Sess. (Ind. 2012), available at http://www.in.gov/legislative/bills/2012/IN/IN1115.1.html (proposing to amend IND. CODE $\S 24-4-18$ to include spray tanning regulations for minors); see, e.g., S. 2119, 214th Leg.., 2d Ann. Sess. (N.J. 2010), available at http://www.njleg.state.nj.us/2010/Bills/S2500/

2119_I1.HTM ("Persons between 14 and 18 shall not be permitted to use spray tanning in this facility without written authorization of a parent or legal guardian.").

179 ARIZ. REV. STAT. ANN. § 32-506(12) (2013) (effective Aug. 2, 2012) ("This chapter does not apply to the following persons while in the proper discharge of their professional duties...[p] ersons who provide tanning services by means of airbrushing, tanning beds or spray tanning."); NEB. REV. STAT. § 38-1075(11) (2012) ("The Cosmetology, Electrology, Esthetics, Nail Technology, and Body Art Practice Act does not apply to or restrict the activities of the following: . . . [a]ny person or licensee engaged in the practice of airbrush tanning . ...").

180 Ind. H.R. 1115. This legislation seeks to protect minors, but it does not include adults who are unaware of the dangers posed by spray tanning, specifically the inhalation or ingestion of DHA. Further, the purpose of this proposed house bill is to prevent criminal activity on the part of the spray tan applicator. Compare Maureen Hayden, News from Terre Haute, Indiana: Bill Would Restrict Spray-Tanning for Teens, CNHI STATEHOUSE BUREAU (Jan. 12, 2012), http://tribstar.com/

indiana_news/x1267391974/Bill-would-restrict-spray-tanning-forteens/print (discussing a bill that would require teenagers who want to be spray-tanned in the nude to be accompanied by a parent or guardian), with State v. Huffman, 847 N.E.2d 58 (Ohio Ct. App. 2006), affd, 872 N.E.2d 1213 (Ohio 2007) (defendant convicted for violating OH. REV. CODE ANN. $§ 2907.08$ for recording various adult and minor female tanning salon customers during tanning bed and spray-on booth usage).

181 Sunlight Found., $H B$ 1115, Indiana - Last Activity on Jan. 9, 2012, ScOUT, https://scout.sunlightfoundation.com/item/state_bill/ INB00002008?follow=now (last visited Feb. 9, 2013); Hayden, supra note 180 ("No vote was taken on the bill; it's expected to come up for a vote at a later committee hearing."). 
approval for minors using indoor UV tanning beds. 182 However, the bill seeks only to protect minors, and it does not include adults who are also unaware of the dangers posed by spray tanning, specifically the inhalation or ingestion of DHA. Nevertheless, Indiana may become one of the leading states in spray tanning legislation. If enacted, this bill may be one of many that seek to adequately protect spray tan consumers from the unknown dangers associated with frequent exposure to sunless tanning solution.

\section{FUTURE INDOOR SPRAY TANNING REGULATIONS}

There is an absence of both federal and state supervision of commercial spray tanning establishments. ${ }^{183}$ All of the recent regulations of the tanning industry have been restrictions on the use of UV tanning. ${ }^{184}$ Because the current state of indoor tanning regulation does not extend to spray tanning booths, consumers are not adequately protected or informed about the unknown risks associated with long-term human exposure to sunless tanning solutions. While salons can offer the application of a spray tan, it must be made clear that the use of a spray tan booth is not FDA approved. In light of this fact, this Section discusses multiple avenues for future regulation of the spray tanning industry, including more rigorous federal regulations, enhanced state regulations, and the possible adoption of a uniform age requirement for spray tan application.

\section{A. Rigorous Federal Regulation of the Indoor Spray Tanning Industry}

The FDA should monitor, restrict, or regulate spray tan application more stringently both on a national and local

182 IND. CODE $\S 25-8-15.4-15,16$ (2013); Hayden, supra note 180 (describing the proposed bill as being "much like the current state law that requires parental approval for minors using indoor-tanning booths.").

183 Fu et al., supra note 11 , at 710.

184 See ARIZ. REV. STAT. ANN. § 15-718 (2012); see sources cited supra note 157 . 
level. To adequately protect the American public, the U.S. federal government should enact "[u]niform guidelines . . . to address safety issues associated with sunless tanning booth use. Future investigations are warranted to assess both the medical and behavioral implications of perpetuating the aesthetic appeal of the tan."185 Additional licensure requirements and increased salon inspection could be useful as well. ${ }^{186}$

Sun protection is key to human health, and there is evidence that spray tanning and the use of sunless tanning products do little to change sun protection patterns, as "the majority of individuals undergoing spray-on sunless tanning do not alter their sun exposure or their sunscreen use as a result of using sunless tanning." 187 A recent report further supports this notion, as " $10.8 \%$ of American adolescents used sunless-tanning products and ... this practice was associated with risky UV-radiation exposure-related behaviors, including natural and artificial radiation." 188 Thus, federal authorities must ensure that consumers are aware that the use of spray tanning and other sunless tanning products will not increase protection against the unwanted human health hazards associated with UV exposure. Most importantly, the uniform application of a federal regulation across the nation would provide the greatest consumer protection, as salons and consumers alike would probably experience less confusion in locating and understanding the law.

185 Fu et al., supra note 11 , at 706.

186 Id. at 711 ("Although the FDA advises consumers to ask for appropriate protection against [unwanted sunless tanning] exposures, at this time, mechanisms for licensing and inspecting commercial facilities with sunless tanning booths are lacking.") (internal citation omitted).

187 Sheehan \& Lesher, supra note 2 , at 1192.

188 E. Tella et al., French Teenagers and Artificial Tanning, J. OF EUROPEAN ACAD. OF DERMATOL. AND VENEREOLOGY (2012). 


\section{B. Enhanced State and Local Health Authority Regulation of Indoor Spray Tanning}

As no current spray tanning regulations exist at a federal or state level, consumers would benefit greatly from state action. Following the trend of greater regulation of UV tanning beds, 189 spray tanning devices should be included within every state statutory scheme regulating indoor tanning facilities. As legislation alone is insufficient to restrict access to artificial UV radiation-emitting sun beds, 190 the states may need to employ other mechanisms to safeguard consumers and may need to enlist local health authorities in this endeavor. Because many states have passed legislation $n$ limiting youth access to indoor $U V$ radiation exposure, ${ }^{191}$ the states should also consider the potential human health hazards associated with the misting of sunless tanning solutions. Accordingly, preventive state efforts are necessary to protect the American public.

State legislatures should consider public policy interests, potential detrimental health outcomes from continued exposure to sunless tanning solutions, and examples of proposed or evolving legislation in other states that seek to protect the public from chemical inhalation and absorption during spray tan application. In looking to similar industries, state legislatures could compare potential sunless tanning regulation to UV tanning regulation, 192 tobacco regulation, 193 and alcohol regulation. ${ }^{194}$ Most

189 See supra Section IV. B. 1.

190 Makin et al., supra note 77, at 292.

191 Latrice C. Pichon et al., Youth Access to Artificial UV Radiation Exposure: Practices of 3467 US Indoor Tanning Facilities, 145 ARCH. DERMATOL. 997, 1001 (2009).

192 See supra Section IV. A, B.

193 Obayan, Legislation Restricting Tanning Access, supra note 66, at 68 (discussing that "the following have been found to increase effectiveness of tobacco policy: (1) study of existing laws to measure effectiveness of the policy; (2) assessment of the legal limitations of the policy; (3) analysis of the legislative cycle to determine the most optimal time at which to propose the legislation; and (4) gathering information on past voting records of potential supporters of the legislation . . . the strategies used to draft and enforce effective tobacco policy would be 
importantly, state authorities should endeavor to conduct studies on the potential health effects associated with continued exposure to sunless tanning solution.

In order to avoid inhalation or absorption of the sunless tanning solution into any mucous membrane, state regulations should mandate that consumers wear protective eyewear and cover the lips and nostrils during spray tan application to ensure greater consumer protection. ${ }^{195}$ While additional regulations are desirable, each state must ensure effective enforcement mechanisms are in effect to incentivize salon and consumer compliance. Without proper enforcement, safety precautions adopted by the states would likely be futile. ${ }^{196}$ By way of the tanning tax as well as licensure and permitting requirement, the states can acquire the necessary funds to ensure that the enacted regulations are implemented as intended.

\section{Nationwide Minimum Age Requirements for Indoor Spray Tanning}

A more extreme approach to addressing the dangers associated with spray tanning use is the option for the FDA or individual states to enact nationwide minimum age requirements for spray tan application. Salon employees should know of the potential dangers associated with DHA and should be adequately trained to prevent customers from inhaling or ingesting the solution during spray tan application. This subsection suggests that uniform

similarly beneficial when applied to policy restricting youth access to tanning beds.").

194 Mayer et al., supra note 74 , at 4 ("As is the case with enforcement activities regarding tobacco and alcohol control, businesses are less likely to comply with age-of-sale laws if noncompliance is not penalized.") (internal citations omitted).

195 Sunless Tanners Guidance, supra note 24 ("Consumers should request measures to protect their eyes and mucous membranes and prevent inhalation.").

196 Mayer et al., supra note 74 , at 3 (discussing that in a 2008 study "data indicate that routine annual inspections, which are a prerequisite for other enforcement activities such as levying penalties for violations" are not conducted in the majority of indoor UV tanning salons.). 
legislative enforcement of a nationwide spray tanning age restriction would be the most effective way to protect the American youth. ${ }^{197}$

Legislators could look to UV tanning legislation to pave the way for a nationwide minimum age restriction for the use of spray tanning booths as well. ${ }^{198}$ Balancing the triad of parental autonomy, child interests, and state interests, many states presently regulate minors' exposure to UV tanning beds through age restrictions, parental consent, and parental presence. ${ }^{199}$ Such an approach could be beneficial in restricting minors' access to spray tan application as well. Consistent with the FDA's approach to regulating other carcinogens, the FDA is likely to continue to allow adult users to make individual risk assessments with respect to tanning use, including both UV bed and spray tan exposure. ${ }^{200}$ Nevertheless, both federal and state governments have an interest in protecting the American youth, as children are often too immature and too vulnerable to advance their own interests or exercise their own rights- which are limitations the law has recognized. ${ }^{201}$ Because continued exposure to sunless tanning solutions

197 Makin et al., supra note 77, at 291 ("In the United States, compliance with state laws restricting access [to indoor tanning facilities] for minors has been found to be less than optimal, potentially partly due to lack of enforcement.") (internal citations omitted).

198 Pulley, supra note 68, at 1207-11 (discussing the possibility of a nationwide minimum age restriction or a nationwide ban on indoor $\mathrm{UV}$ tanning bed usage as of 2009).

199 See supra Part IV.B.1.

200 Family Smoking Prevention and Tobacco Control Act, Pub. L. No. 111-31, § 2, 123 Stat. 1776, 1777 (2009) ("Federal and State governments have lacked the legal and regulatory authority and resources they need to address comprehensively the public health and societal problems caused by the use of tobacco products."); see Knapp, supra note 10 , at 38 ("FDA and Congress allowed saccharin to stay on the market despite concerns that it caused cancer . . . because the public was attached to its benefits.") (internal citations omitted).

201 See, e.g., Prince v. Massachusetts, 321 U.S. 158 (1944) (discussing how to allocate authority among parents, the child, and the state to make important decisions affecting the child and holding that parents are not free to make martyrs of their children before such time as the children have reached the age of full and legal discretion to make that choice for themselves). 
has not been researched on humans, a nationwide age minimum on the use of spray tanning booths would be the best preventative measure to ensure that all minors within the U.S. are uniformly protected against this uninvestigated product.

\section{REGULATORY ALTERNATIVES}

While current regulation of the indoor tanning industry combined with the aforementioned recommendations will ensure that indoor tanning is as safe as possible, regulation alone is insufficient to safeguard consumers. ${ }^{202}$ At present, regulation of the indoor UV tanning industry is still evolving, and the use of spray tanning facilities is not regulated at all. Therefore, this section considers possible non-regulatory alternatives to supplement indoor tanning regulation. This section explores some possible alternatives including: promoting consumer education, encouraging salon self-regulation, education, and appropriate advertising, and endorsing safer alternatives to achieving a tanned appearance. Beyond these basic alternatives, this section suggests that changing perceptions about desirable skin tones may be the fundamental change necessary to sway societal attitudes away from artificial tanning practices.

\section{A. Promoting Consumer Education}

One non-regulatory alternative to provide greater protection for indoor tanning consumers is to increase the amount of information available to consumers regarding the dangers of tanning. While public education initiatives aimed at reducing consumer exposure to uninvestigated chemicals such as spray tanning solutions may be difficult

202 See, e.g., Pawlak, supra note 6, at 1010 ("Other interventions could assist in decreasing youth indoor tanning, including promoting public health announcements, implementing a tanning bed use tax, restricting marketing directed toward youth, restricting the location of tanning salons, and mandating education for tanning bed users."). 
at first, ${ }^{203}$ a change in social attitudes moving away from tan-seeking practices and progressing towards an increased desire for adequate assurances of health and safety is not impossible. ${ }^{204}$ This sub-section advocates for a more comprehensive educational scheme directed towards the American public to promote consumer health education initiatives which, to dissuade detrimental tanning practices, should be employed by medical societies, ${ }^{205}$ state and local health organizations, federal and state governments, and by media outlets through public health announcements. ${ }^{206}$

The lack of human studies regarding continued exposure to sunless tanning products is a serious public health issue. The carcinogenic effects of human UV exposure are also alarming. Preliminary research indicates that the primary chemical ingredient in spray tan solutions, DHA, may cause genetic mutations to cells and other potential human harms. ${ }^{207}$ While there is no current evidence that spray tanning causes cancer, there is not any evidence that this

203 Martin et al., supra note 7, at 2140 ("Despite public education initiatives aimed at preventing skin cancer, many individuals continue to tan, citing such reasons as the relationship between tanning and physical and emotional health, an active lifestyle, and physical beauty.") (internal citations omitted).

204 Paul et al., supra note 14, at 930 ("In Australia, ongoing public education campaigns such as Sunsmart have had some success in reducing population exposure to UV light and the numbers reported to actively seek a tan.") (internal citations omitted).

205 Martin et al., supra note 7, at 2145 (these societies could include the following: the American Medical Association, the American Academy of Dermatology, the American Academy of Pediatrics, the Endocrine Society, and the American Society for Nutrition).

206 Pawlak, supra note 6, at 1010 ("Although it is difficult to establish the exact role and value of mass media interventions, such as public health announcements through television, radio, billboards, and newspapers [in regards to the indoor tanning industry], on tobacco cessation, various studies showed positive results on smoking behavior for up to [eight] years after the campaign.") (citing Bala M, Strzeszynski L \& Cahill K, Mass Media Interventions for Smoking Cessation in Adults (Review), THE COCHRANE Collaboration (2008), http://www.cmtabaquismo.com.ar/documentos/Balacochrane\%20sobre\% 20intervenciones\%20en\%20los\%20medios.pdf).

207 See supra Section II. A. 
practice is safe. ${ }^{208}$ Tanning salons offer spray tanning to consumers without FDA approval of this practice. Consumers have the right to know that exposure to sunless tanning solution as a misted-on spray is potentially unsafe.

Accordingly, proper health care initiatives and policies must be in place to protect future generations from the potential health risks associated with tanning practices. For this reason, additional research may be necessary. Additional research may better facilitate the development of effective public health education initiatives by more fully understanding the long-term underpinnings of current social attitudes towards sun exposure, UV tanning bed usage, and spray tan application. ${ }^{209}$ Education is a necessary component of preventive campaigns against the use of spray-on sunless tanning products. ${ }^{210}$ However, education alone may be an insufficient means of regulating the harmful effects of indoor tanning products. ${ }^{211}$

208 See, e.g., Philip Caulfield, Spray Tanning Could Cause Cancer: Report, NEW YoRK DAlly NEWS (June 13, 2012, 1:32 PM), http://www.nydailynews.com/life-style/health/spray-tanning-cancerreport-article-1.1094938?localLinksEnabled=false ("Medical experts warn that key ingredient in tanning spray could be harmful if inhaled."); Spray Tanning May Cause Cancer, Too, FIndLAW.COM (June 14, 2012), http://commonlaw.findlaw.com/2012/06/spray-tanning-maycause-cancer-too.html ("New information indicates that spray tanning may cause cancer; just when you thought it was safe.").

209 Martin et al., supra note 7, at 2145 (suggesting that "[m]edical societies need to collaborate on a unified statement with recommendations on nutrition, vitamin $\mathrm{D}$ supplementation, and UV prevention" to develop effective public health education initiatives to discourage indoor UV tanning practices).

210 Tella et al., supra note 188 ("Given the prevalence of indoor UV tanning in France, especially by teenagers, despite its being forbidden by law, and its known risks, public health authorities must enforce compliance with the legislation and focus its prevention campaigns on at-risk teenagers."); Katie Brooks et al., Use of Artificial Tanning Products Among Young Adults, 56 J. AM. ACAD. DERMATOL. 1060, 1065 (2006) ("[T]he manufacturers of artificial tanning products have a responsibility to inform consumers of the content of the product, and the risks involved with product use.").

211 Makin et al., supra note 77, at 291 ("[G]overnment regulation of the indoor tanning industry is indeed a better whole-population approach to this health issue than voluntary standards and/or industry or consumer education."). 
Additional non-regulatory alternatives should also be considered.

\section{B. Encouraging Self-Regulation, Operator Education, and Appropriate Advertising by Salons}

Another non-regulatory alternative to increase consumer protection could be implemented by the industry itself. While there is evidence of an industry-backed comprehensive national program to reinforce the FDA's safety recommendations during spray tan application, will this result in improved compliance everywhere? ${ }^{212}$ This sub-section seeks to encourage self-regulation amongst tanning salons, to promote training for indoor tanning bed and spray tan booth operators, and to support appropriate advertising by salons. These practices could be promoted among indoor tanning facilities because such initiatives may increase consumer confidence in the industry. ${ }^{213}$

While some states already mandate training for indoor UV tanning bed operators, ${ }^{214}$ no such regulations are in

$212 \mathrm{Fu}$ et al., supra note 11, at 710 ("[T]he National Tanning Training Institute has begun to advertise a sunless tanning certification course similar to courses in UV tanning, popular in states that require the training of personnel for salon licensing.").

213 Nat'l Tanning Training Inst., Online Training, TANNINGTRAINING.COM, http://www.tanningtraining.com/ (last visited July 7, 2013) ("Professional expertise granted through NTTI's online programs has helped to increase tanning consumer confidence with the most up-to-date information available in the industry.").

214 See ARIZ. ADMIN. CODE § R12-1-1414(A)(2) (2013) (tanning equipment operators); ARK. CODE ANN. § 20-27-2201(2)(A) (2013) (effective July 31, 2009) (definitions); CAL. BUS. AND ProF. CODE $\S$ 22706(b)(3) (2013) (operating regulations, customer acknowledgement of warnings; use of facilities by minors); COLO. REV. STAT. $§ ~ 25-5-1007$ (2013) (owner responsibilities); CONN. GEN. STAT. § 19a-232 (2013) (tanning facilities); 16 DEL. CoDE ANN. tit. 16, § 3002D(4) (2013) (effective Aug. 13, 2009) (definitions); FLA. STAT. $§ 381.89(7)$ (2013) (regulation of tanning facilities); GA. CODE ANN. $\S 31-38-7$ (2013) (protective goggles); 210 ILL. COMP. STAT. ANN. 145/25 (West 2012) (operating requirements); IND. CODE $\S$ 25-8-15.4-14 (2013) (duties of operator); IOWA CODE $\S 136 \mathrm{D} .7$ (2013) (duties of department); KAN. STAT. ANN. § 65-1924 (2013) (presence of trained operator required); KY. REV. STAT. ANN. $§ 217.924$ (West 2012) (requirements for tanning 
place for the operation of spray tanning booths. The promotion of self-regulation will lead to operators being properly trained for both UV and spray tanning devices. ${ }^{215}$ While training requirements vary amongst salons and by state, important elements to any training program include education about the proper use of salon equipment and knowledge of the risks associated with such use. Educated salon operators will be better equipped to instruct consumers on how to adequately protect themselves from inhalation and prohibited absorption during spray tan application. Appropriate advertising schemes by the tanning industry and individual salons will more adequately protect consumers through product awareness as well. ${ }^{216}$

facilities); LA. REV. STAT. ANN. $\& \quad 40: 2713$ (2013) (operational requirements); 10-144 DEPT. OF HUMAN SERVICES ch. 223 12A(3)(f) (2013) (effective Mar. 1, 1991) (rules relating to tanning facilities); MASS. GEN. LAWS ch. 111, § 210 (2013) (presence of operators); MICH. COMP. LAWS $\S 333.13405(1)$ (2013) (effective Dec. 23, 2008) (use of tanning devices); MINN. STAT. $\S 325 \mathrm{H} .03$ (2013) (standards for tanning equipment); N.H. REV. STAT. ANN. § 313-A:30 (2013) (operational requirements); N.J. STAT. ANN. § 26:2D-83 (2013) (effective June 29, 2012) (minimum safety standards; establishment by regulation; signage); N.C. GEN. STAT. § 104E-9.1(a)(1) (2013) (restrictions on use and operation of tanning equipment); N.D. CENT. CODE $§ 23-39-05$ (1)(a) (2013) (effective Aug. 1, 2007) (duties); OHIO REv. CODE ANN. § 4713.48 (2013) (regulation of tanning facilities); OR. ADMIN. R. 333-119-0090(2) (2013) (protection of consumers); R.I. GEN. LAWS $\S 23-68-4(6)$ (2013) (effective Jan. 1, 2013) (safety standards established); TENN. CODE ANN. $\S 68-117-104(\mathrm{a})(1)$ (2013) (duties); TEX. HEALTH \& SAFETY CODE ANN. § 145.008 (West 2010) (operational requirements); UTAH CODE ANN. § 2615-13 (West 2012) (regulation of tanning facilities); VT. STAT. ANN. tit. $18, \S 1513(\mathrm{a})(1)$ (2013) (effective July 1, 2012) (tanning facilities); VA. CODE ANN. \$59.1-310.5 (2013) (effective July 1, 2007) (operational requirements); WIS. STAT. § 255.08(9)(b) (2013) (tanning facilities).

215 The National Tanning Training Institute (NTTI) offers five online courses: a basic tanning certification, a salon operations and procedures course, a lotions and skincare course, an introduction to sunless tanning, and a sunless airbrush technician course. Nat'l Tanning Training Inst., supra note 213.

216 Martin et al., supra note 7, at 2145 ("Advertisements continue to promote tanning, even in high school newspapers, despite substantial scientific evidence that tanning-bed use correlates with skin cancer." (footnotes omitted)). 


\section{Endorsing Safer Alternatives to Achieving a Tanned Appearance}

Spray tanning devices were introduced to the market as a safer alternative to indoor UV tanning practices. However, spray tan exposure "has not been well studied in the context of skin cancer prevention."217 Spray tans have not been scientifically investigated and are therefore not proven to be safe. Similarly, exposure to indoor UV tanning beds is known to be carcinogenic. ${ }^{218}$ For these reasons, the tanning industry could promote sunless tanning lotions as a safer alternative to indoor UV tanning bed use or spray tan application. The FDA endorses the use of sunless tanning products sold in retail stores such as creams and lotions. ${ }^{219}$ Although individual tanning salons may see this method as detrimental to the industry, product manufacturers may endorse the promotion of sunless tanning lotions.

Under the authority of the FPLA, the FDA "requires ingredient declarations on cosmetics sold on a retail basis to consumers." 220 By purchasing sunless tanning lotions and creams from a retail store, consumers have access to full knowledge of the ingredients contained in these products, and can avoid potentially harmful ingredients. However, consumers do not have this courtesy when utilizing commercial spray tanning facilities, as the "FPLA does not apply to products used exclusively by professionals, such as those used in spray tanning booths."221 Until research is conducted on the effects of spray tan absorption and inhalation on the human body, consumers could benefit greatly from the promotion of safer alternatives to achieving a tanned appearance.

217 Sherry L. Patogo et al., The Sunless Study: $A$ Beach Randomized Trial of a Skin Cancer Prevention Intervention Promoting Sunless Tanning, 146 ARCH. DERMATOL. 979, 982 (2010).

218 Brod, supra note 11.

219 Sunless Tanners Guidance, supra note 24 ("DHA is approved for external application to the human body, which is the way [creams and lotions] are intended to be used.").

$220 \mathrm{Id}$.

$221 I d$ 


\section{Changing Perceptions About Desirable Skin Colors}

Despite additional regulation, education, and the availability of healthier alternatives, many Americans continue to frequent tanning facilities. ${ }^{222}$ Encouraging consumers to stop tanning, however, will "require a fundamental change in the societal belief that tans are attractive and healthy." 223 While tanning allegedly makes individuals look darker, healthier, and thinner, "unknown are the specific dimensions of how body-tanning functions in achieving attractiveness among adolescents." 224 Likewise, "further investigations are needed to evaluate the behavioral implications of continuing to perpetuate the aesthetic appeal of the tan."225

A fundamental change in the societal perceptions about desirable skin colors will be a slow transition, but it is a movement that may benefit the U.S. public as a whole. In the meantime, the aforementioned regulatory and nonregulatory alternatives should be encouraged and implemented by federal and state governments, local and national health authorities, and organizations generally concerned with the health of the U.S. public. Indoor

222 Am. Acad. of Dermatology, Indoor Tanning, AAD.ORG, http://www.aad.org/media-resources/stats-and-facts/prevention-andcare/indoor-tanning (last visited July 7, 2013) ("On an average day in the United States, more than [one] million people tan in tanning salons . . Nearly [twenty-eight] million people tan indoors in the United States annually. Of these, 2.3 million are teens.") (internal citations omitted); Compare Cokkinides, supra note 172, at 987 ("The prevalence of selfreported use of sunless tanning products in the past year among US adolescents was 10.8\%."), with Veronica A. Russo et al., Patterns of Use of Sunless Tanning Product Alternatives to Indoor Tanning Among Female College Students, 148 ARCH. DERMATOL. 855 (2012) (a 2012 study showed that eighty-seven percent of female college student participants used sunless tanning products).

223 Pulley, supra note 68, at 1223 (quoting J. Matthew Knight et al., Awareness of the Risks of Tanning Lamps Does Not Influence Behavior Among College Students, 138 ARCH. DERMATOL. 1311 (2002)).

224 Jeong-Ju Yoo \& Hye-Young Kim, Adolescents' Body-Tanning Behaviours: Influence of Gender, Body Mass Index, Sociocultural Attitudes Towards Appearance and Body Satisfaction, 36 INT'L J. OF CONSUMER STUDIES 360, 365 (2012).

225 Fu et al., supra note 11 , at 712 . 
tanning practices should be as safe as possible, and regulatory schemes as well as educational initiatives may help to achieve this purpose.

\section{CONCLUSION}

For the past three decades, federal and state governments as well as health advocates have been working towards regulating the indoor tanning industry, a desirable service with detrimental health effects. In response to the carcinogenic properties of UV tanning bed exposure, the rapidly growing sunless segment of the indoor tanning industry was promoted as a safer alternative to achieving the desired dark appearance. Because of the uninvestigated long-term health effects of repeated exposure to spray tanning solutions with the active ingredient of DHA, the spray tanning industry should be more heavily regulated on both a federal and state level. Consumers should be adequately informed of the limited scientific knowledge about the potential threats that spray tanning solutions may pose to the human body. Without such awareness, consumers will be unable to make informed decisions about spray tanning practices.

The FDA and other health organizations should undertake investigations regarding the frequent exposure to and absorption of all sunless tanning products, with a specific inquiry into the safety of spray tans applied with misters. The collection of such scientific data will allow health authorities to identify risk factors associated with these products, which will in turn enable the federal and state governments to more adequately protect consumers. Before any endorsements are made of the sunless tanning booth, further investigations are necessary to evaluate the potential human health hazards associated with the 
continued use of DHA in spray tan application. ${ }^{226}$ Tanned skin is a sign of injury and "healthy" tans do not exist.227

226 Brooks et al., supra note 210, at 1065 ("While safe alternatives to prolonged sun exposure or use of tanning beds are desirable, the potential risks of endorsing artificial tanning products must be thoroughly considered.").

227 Sun Safety, AM. SKIN ASS'N, http://www.americanskin.org/ resource/safety.php (last visited July 6, 2013). 